Biogeosciences Discuss., https://doi.org/10.5194/bg-2018-306

Manuscript under review for journal Biogeosciences

Discussion started: 2 August 2018

(c) Author(s) 2018. CC BY 4.0 License.

\title{
Potential effects of deep seawater discharge by an Ocean Thermal Energy Conversion plant on the marine microorganisms in oligotrophic waters
}

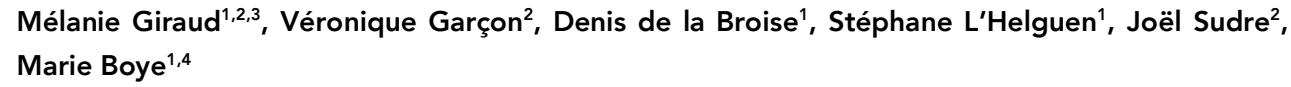

\section{Abstract}

Installation of an Ocean Thermal Energy Conversion pilot plant (OTEC) off the Caribbean coast of Martinique is expected to use approximately $100000 \mathrm{~m}^{3} \mathrm{~h}^{-1}$ of deep seawater for its functioning This study examined the potential effects of the cold nutrient-rich deep seawater discharge on the phytoplankton community before the installation of the pilot plant. Thermal effect induced by the deep seawater upwelled by the OTEC was described using the Regional Ocean Modeling System. Numerical simulations of deep seawater discharge showed that a $3.0^{\circ} \mathrm{C}$ temperature change, considered as a critical threshold for temperature impact, was never reached during an annual cycle on the top $150 \mathrm{~m}$ of the water column on two considered sections centered on the OTEC. The thermal effect should be limited, less than $1 \mathrm{~km}^{2}$ on the area exhibited a temperature difference of $0.3^{\circ} \mathrm{C}$ (absolute value). The impact on phytoplankton of the resulting mixed deep and surface seawater was evaluated by in situ microcosm experiments. Two scenario of water mix ratio ( $2 \%$ and $10 \%$ of deep water) were tested at two incubation depths (deep chlorophyll-a maximum: DCM and bottom of the euphotic layer: BEL). The larger impact was obtained at DCM for the highest deep seawater addition (10\%), with a development of diatoms, whereas $2 \%$ addition induced only a limited change of the phytoplankton community. This study suggested that the OTEC plant would significantly modify the phytoplankton assemblage only in the case of a discharge affecting the DCM and would be restricted to a local scale.

\section{Introduction}

Ocean Thermal Energy Conversion (OTEC) uses the solar energy by exploiting the temperature gradient between surface and bottom seawater. In an OTEC plant, the cold deep seawater pumped close to sea bottom is used to condense a working fluid (like ammonia), whereas warm surface waters, pumped close to the surface, serve to evaporate it. The difference of pressure, generated by the evaporation and condensation of the fluid, drives a turbine that produces mechanical energy. 
Biogeosciences Discuss., https://doi.org/10.5194/bg-2018-306

Manuscript under review for journal Biogeosciences

Discussion started: 2 August 2018

(c) Author(s) 2018. CC BY 4.0 License.

This energy is then converted to electrical energy in a generator. Due to the need of a $20^{\circ} \mathrm{C}$ difference between the cold deep and the warm surface waters for the OTEC exploitation, tropical areas are well suited for the installation of OTEC plants.

The Martinique, a tropical island of Lesser Antilles, is ideally suited for OTEC functioning with its narrow continental slope in the Caribbean part of the island, allowing an implementation of the plant close to the coast. The implementation of a $10 \mathrm{MW}$ OTEC pilot plant off the Caribbean coast of Martinique is expected in 2020 as part of the french NEMO project (Akuo Energy, DCNS). This OTEC will pump approximately $100000 \mathrm{~m}^{3} \cdot \mathrm{h}^{-1}$ of deep seawater at $1100 \mathrm{~m}$ depth. In order to optimize the energy efficiency, the deep seawater should be rejected close to the surface. However, this large discharge could induce important disturbances on the upper ocean ecosystem, and this impact should be estimated.

Environmental assessment of OTEC functioning was studied since the 1980's (NOAA, 1981; 2010). The deep seawater discharge was described as one of the major drivers impacting the marine environment in OTEC plant. However, only a few studies specifically detailed this critical aspect (Taguchi et al., 1987; Rocheleau et al., 2012). The deep seawater discharge in OTEC plant generates a phenomenon similar to the one naturally occurring in the ocean within upwelling systems. Equatorward winds along the coast in the eastern Atlantic and Pacific linked to atmospheric highpressure systems force Ekman transport and pumping, relocating coastal surface waters offshore. Thereby, deep water transport towards the surface is generated close to the coast. In these systems, the large amount of macronutrients and trace metals carried to the euphotic zone by the enriched deep seawater supports a large development of the phytoplankton, making upwelling the most productive oceanic regions (Bakun, 1990; Pauly and Christensen, 1995; Chavez and Toggweiler, 1995; Carr and Kearns, 2003). The tropical surface waters off the Caribbean coast of Martinique exhibit low nutrients concentrations and can be significantly enriched by the deep seawater discharge. Whereas phytoplankton assemblages in upwelling systems are usually dominated by large phytoplankton and particularly by diatoms (Bruland et al., 2001; Van Oostende et al., 2015), the phytoplankton community in oligotrophic systems is composed of smaller organisms (Agawin et al., 2000).

Due to these important differences, it is thus of critical interest to investigate the potential effects of the deep seawater discharge of the planned OTEC plant on the phytoplankton community off Martinique.

In this study, the impact of deep seawater discharge on the thermal structure of surface waters was first assessed. Modification of the surface waters stratification should indeed impact the phytoplankton community. It is crucial to provide a depth where the deep seawater could be 
Biogeosciences Discuss., https://doi.org/10.5194/bg-2018-306

Manuscript under review for journal Biogeosciences

Discussion started: 2 August 2018

(c) Author(s) 2018. CC BY 4.0 License.

discharged without significant effect on the surface layer where phytoplankton is the most abundant.

A high-resolution oceanic model was used to examine the thermal impact induced by the deep seawater dispersion. Eight configurations of discharge depth were tested, corresponding to the deep chlorophyll-a maximum (DCM), the bottom of the euphotic layer (BEL) and five depths below the BEL. Temperature differences between numerical simulations without and with the deep seawater discharge were compared on the upper $150 \mathrm{~m}$ of a vertical section.

The distribution of the ambient phytoplankton community and the biogeochemical properties of the deep and surface seawater mixture that could impact the phytoplankton community were then described. Phytoplankton distribution and assemblage were detailed in order to assess short time and small scales variabilities of phytoplankton assemblage and primary production in the study site.

Finally, in order to simulate the OTEC deep seawater input, enrichment experiments were conducted on the future site of the pilot plant. Enrichment experiments are commonly used in oceanography to assess the effects on phytoplankton community and primary production. For example, large iron ( $\mathrm{Fe}$ ) enrichment experiments were conducted from 1993 to 2005 to estimate the potential of Fe limitation on ocean primary production (De Baar et al., 2005; Boyd et al., 2007). Several experiments also showed that macro- and micro-nutrients enrichments induce changes in the phytoplankton community in upwelling regions (Hutchins et al., 2002) as well as in oligotrophic regions (Kress et al., 2005). Enrichment experiments were usually conducted with mesocosms immerged close to the surface (Escaravage et al., 1996; Duarte et al., 2000) or in laboratory under artificial light and temperature using phytoplankton model species (Brzezinski, 1985). A laboratory experiment intended to evaluate the effects of an OTEC seawater discharge in Hawaiian waters on the natural phytoplankton community was previously conducted (Taguchi et al., 1987) under such artificial conditions, and thus, it could not totally reproduce what occurred in the natural environment. Other deep seawater discharge experiments were realized in situ (Aure et al., 2007; Handå et al., 2014). For example, the use of a moored platform to upwell deep seawater and discharge it close to the surface has shown an increase in primary production in a western Norwegian fjord where the euphotic zone is nutrient-depleted during summer (Aure et al., 2007), as it would be expected with the OTEC discharge. Whereas such a pumping system is well adapted for pumping seawater at $30 \mathrm{~m}$ depth for example, it cannot be applied for OTEC experiments where deep seawater must be collected far deeper (1100 m depth) and also discharged more deeply in the water column to reduce the potential effects on the phytoplankton community. These conditions can be obtained by the use of in situ microcosms, in which light and temperature are the same as in the natural surrounding waters, avoiding additional bias, and several conditions (enrichment, incubation 
Biogeosciences Discuss., https://doi.org/10.5194/bg-2018-306

Manuscript under review for journal Biogeosciences

Discussion started: 2 August 2018

(c) Author(s) 2018. CC BY 4.0 License.

101

102

103

104

105

106

107

108

depth) can be simulated. Therefore, we used the unique device of immerged microcosms we developed (Giraud et al., 2016) for assessing the effects of deep seawater discharge on the phytoplankton community. Two incubation depths (DCM and BEL) with two ratios of enriched seawater (mixtures of surface water with $2 \%$ and $10 \%$ of deep seawater) were tested. These experiments allowed the evaluation of critical mixing rate and discharging depth where effect was maximal.

\section{Materials and methods}

\subsection{Modelling the thermal effect}

The hydrodynamic numerical model ROMS-Regional Ocean Model System (Shchepetkin and McWilliams, 2005; 2009) was used to describe the resulting thermal effect due to OTEC functioning. The model was run in a 2-ways AGRIF configuration allowing to define a parent and child domains around the Martinique Island which are run simultaneously, transferring automatically open boundary conditions. The parent grid ranges from $63^{\circ} \mathrm{W}$ to $59^{\circ} \mathrm{W}$ and $13^{\circ} \mathrm{N}$ to $15.9^{\circ} \mathrm{N}$ with a resolution of $1 / 60^{\circ}$ (around $1.8 \mathrm{~km}$ ) while the child domain narrows the parent one and was from $61.74^{\circ} \mathrm{W}$ to $60.41^{\circ} \mathrm{W}$ and $14.21^{\circ} \mathrm{N}$ to $15.11^{\circ} \mathrm{N}$ with a resolution down to $1 / 180^{\circ}$ (around $600 \mathrm{~m}$ ). The bottom topography and coastline are interpolated from the GINA database $\left(1 / 120^{\circ}\right.$, www.gina.alaska.edu/data/gtopo-dem-bathymetry) (Fig. 1).

The model is forced by the monthly Climate Forecast System Reanalysis (NCEP-CFSR) for wind stress, heat and freshwater fluxes. For the open boundary conditions and initial conditions of the parent domain, a monthly climatology computed from the Simple Ocean Data Assimilation (SODA) reanalysis (Carton and Giese, 2008) was used for the dynamical variables (temperature, salinity and velocity fields). The NCEP-CFSR products do no cover the period of our mesocosm experiments (November 2013 and June 2014). The simulations were thus performed over another period when the atmospheric forcing was available. We choose the 3 years period of 1998-2000, using 1998 and 1999 as a spin-up and the last year 2000 to analyze the thermal structure and circulation field. Model outputs were stored as daily averages. The configurations were run without and with a deep seawater discharge mimicking the OTEC functioning. The deep seawater discharge was initiated on January $1^{\text {st }}$ 2000. Eight cases of horizontal discharge settings were simulated at different depths: 1) the $\operatorname{DCM}(45 \mathrm{~m}), 2)$ the BEL $(80 \mathrm{~m})$, that were estimated on June $12^{\text {th }} 2014$, and 3) six depths below the euphotic zone $(110 \mathrm{~m}, 140 \mathrm{~m}, 170 \mathrm{~m}, 250 \mathrm{~m}, 350 \mathrm{~m}$ and $500 \mathrm{~m})$. In the OTEC plant, deep water will be pumped at $1100 \mathrm{~m}$ where temperature is around $5^{\circ} \mathrm{C}$ and salinity 35 . Circulation of this water through the plant system will warm it up until $8^{\circ} \mathrm{C}$ prior to its release in the upper ocean. We thus 
Biogeosciences Discuss., https://doi.org/10.5194/bg-2018-306

Manuscript under review for journal Biogeosciences

Discussion started: 2 August 2018

(c) Author(s) 2018. CC BY 4.0 License.

applied at the location of the OTEC plant $\left(61^{\circ} 13^{\prime} 0^{\prime \prime} \mathrm{W}, 14^{\circ} 35^{\prime} 48^{\prime \prime} \mathrm{N}\right)$, a cold water discharge (temperature $8{ }^{\circ} \mathrm{C}$, salinity 35 ) at a flow rate of $28 \mathrm{~m}^{3} \mathrm{~s}^{-1}$ and with a northward orientation. The thermal impact of the cold-water source was assessed documenting the differences between simulations without and with the modelled OTEC plant functioning over the full year 2000.

\subsection{Field observations and in situ experiments}

\subsubsection{Sampling and analytical methods}

Temperature, salinity, and fluorescence profiles were performed using Seabird SBE19+ probe with in situ Fluorimeter Chelsea AQUAtracka III.

Seawater was collected in the water column in ultra-clean conditions (Giraud et al., 2016) to measure in situ parameters and to prepare the microcosms. Seawater and microcosms were sampled similarly in a land laboratory a few hours after collection.

Nitrate $\left(\mathrm{NO}_{3}{ }^{-}\right)$, nitrite $\left(\mathrm{NO}_{2}^{-}\right)$, phosphate $\left(\mathrm{PO}_{4}{ }^{3-}\right)$ and silicate $\left(\mathrm{Si}(\mathrm{OH})_{4}\right)$ concentrations were determined in filtered waters $\left(<0.6 \mu \mathrm{m}\right.$ PC membrane) stored at $-20^{\circ} \mathrm{C}$ until analysis using a Bran + Luebbe AAlll auto-analyzer (Aminot and Kérouel, 2007).

Filtered samples $\left(0.2 \mu \mathrm{m} ; 300 \mathrm{AC}-S_{\text {Sartobran }}{ }^{\mathrm{TM}}\right.$ capsules) for dissolved trace metals determination were collected under pure- $\mathrm{N}_{2}$ pressure $(0.7 \mathrm{~atm})$ in acid cleaned low density polyethylene bottles, acidified with ultrapure $\mathrm{HCl}(\mathrm{pH}<2)$ and stored in two plastic bags in dark at ambient temperature. Concentrations of dissolved trace metals (cadmium, $\mathrm{Cd}$; lead, $\mathrm{Pb}$; iron, $\mathrm{Fe}$; zinc, $\mathrm{Zn}$; manganese, $\mathrm{Mn}$; cobalt, $\mathrm{Co}$; nickel, $\mathrm{Ni}$; and copper, $\mathrm{Cu}$ ) were determined in UV-digested samples by ID-ICP-MS (Milne et al., 2010) after preconcentration on a WAKO resin (Kagaya et al., 2009) using an Element XR ICP-MS. Blanks, limits of detection, accuracy and precision (assessed using reference samples) of the ID-ICP-MS method are reported in Table 1. The values determined by ID-ICP-MS were in excellent agreement with the consensus values, apart for $\mathrm{Cd}$ that yielded higher concentration in S-SAFE reference sample than the consensus value (Table 1).

The $\mathrm{pH}$ was determined using a $\mathrm{pH}$ ultra-electrode ( $\mathrm{pHC28}$ ) mounted on a HO4Od multi $\mathrm{pH}$ meter $(\mathrm{HACH})$ with an accuracy of $\pm 0.002 \mathrm{pH}$ unit in samples preserved with saturated $\mathrm{HgCl}_{2}$ in glass bottles hermetically closed with Apiezon grease, sealed with Parafilm ${ }^{\circledR}$ and stored in the dark at ambient temperature.

Three complementary methods were used to analyze the phytoplankton community. Pigment signatures were measured by HPLC (using an Agilent Technologies 1100-series) on polysulfone filters $\left(0.22 \mu \mathrm{m}\right.$ pore-size) frozen at $-20^{\circ} \mathrm{C}$ and stored in liquid nitrogen, after internal standard addition (vitamin $\mathrm{E}$ acetate) and extraction in a $100 \%$ methanol solution (Hooker et al., 2012). Fifty pigments were identified and associated to phytoplankton groups (Uitz et al., 2010). Identification 
Biogeosciences Discuss., https://doi.org/10.5194/bg-2018-306

Manuscript under review for journal Biogeosciences

Discussion started: 2 August 2018

(c) Author(s) 2018. CC BY 4.0 License.

and enumeration of pico-phytoplankton were realized by flow-cytometry using a BD-FACSVerse ${ }^{\mathrm{TM}}$ (Marie et al.,1999) in samples preserved in cryotube with addition of $0.25 \%$ glutaraldehyde frozen at $-20^{\circ} \mathrm{C}$ and stored in liquid nitrogen. Four groups of pico-phytoplankton were identified: Prochlorococcus, picoeukaryotes $(<10 \mu \mathrm{m})$, and 2 groups of Synechococcus discriminated, respectively, by their low and high phycourobilin (PUB) to phycoerythrobilin (PEB) ratios. Taxonomic identification and enumeration of micro-phytoplankton $(20-200 \mu \mathrm{m})$ and a part of nanophytoplankton (2-20 $\mu \mathrm{m}$ ) (Dussart, 1966) were carried out using an inverted microscope (Wild M40) in samples preserved with neutral lugol solution. Utermöhl settling chambers (Hasle, 1988) were used for micro-phytoplankton analyses, and a smaller sedimentation chamber $(2.97 \mathrm{~mL})$ for the analyses of nano-phytoplankton. When possible, phytoplankton was identified to the lowest possible taxonomic level (species, genus or group). Biovolume of each species was also estimated from these microscope analyses (Hillebrand et al., 1999).

\subsubsection{In situ microcosm experiments}

The potential impact of deep seawater discharge on the phytoplankton community was simulated by in situ microcosm incubations of various deep and surface seawater mixing (Giraud et al., 2016). The experiments were conducted from $12^{\text {th }}$ (D0) to $19^{\text {th }}$ (D7) of June 2014. The deep and surface seawaters were collected at the site of the future OTEC pilot plant $\left(61^{\circ} 11^{\prime} 52^{\prime \prime}\right.$ W-14 $37^{\prime} 57^{\prime \prime}$ N; Fig 1). Microcosms bottles were incubated on two stainless steel structures set at the depths of deep chlorophyll-a maximum (DCM) and at the bottom of the euphotic layer (BEL) on a mooring chain located, for practical reasons, closer to the coast $\left(61^{\circ} 10^{\prime} 9^{\prime \prime} \mathrm{W}-14^{\circ} 39^{\prime} 8^{\prime \prime} \mathrm{N}\right.$, seafloor at $220 \mathrm{~m}$ depth) during 6 days (Giraud et al., 2016).

Seawater was collected at D0 at the depths of DCM (45 m depth) and BEL ( $80 \mathrm{~m}$ depth) identified on the future OTEC site from the fluorescence profile, and close to the bottom (1100 m depth corresponding to the pumping depth of the future OTEC plant) in ultra-clean conditions. Deep seawater was mixed in three proportions $(0 \%$ as a control hereafter referred to as "Control", 2 $\%$ as a low input called "2 \% of deep seawater", and $10 \%$ as a large input called "10 \% of deep seawater") with DCM and BEL waters. Each resulting mixture was distributed in $2.3 \mathrm{~L}$ polycarbonate bottles filled up to overflow level, of which four replicates per mixing condition per depth were immersed at their respective sampling-depth for 6 days; duplicates per mixing condition per depth were kept in dark at $25^{\circ} \mathrm{C}$ for a few hours until sampling for later characterization of phytoplankton assemblage and biogeochemical properties at D0 (called "Surrounding waters D0"); and duplicates per mixing condition per depth were used to estimate carbon and $\mathrm{NO}_{3}{ }^{-}$uptakes at $\mathrm{D} 0$ (called "Surrounding waters D0") as described below. 
Biogeosciences Discuss., https://doi.org/10.5194/bg-2018-306

Manuscript under review for journal Biogeosciences

Discussion started: 2 August 2018

(c) Author(s) 2018. CC BY 4.0 License.

Same sampling and mixtures were realized at day $6\left(D 6\right.$, June $\left.18^{\text {th }}\right)$ just to evaluate the temporal evolution in the natural environment, resting on duplicate bottles per mixing condition per depth for phytoplankton and biogeochemical characterizations at D6 (called "Surrounding waters D6") and using other duplicates to estimate carbon and $\mathrm{NO}_{3}$-uptakes at D6 (called "Surrounding waters D6").

After the 6 days incubation, all the incubated microcosm bottles on the mooring (called "Microcosm D6") were brought on board. A quarter of each four replicates per condition was put in a new $2.3 \mathrm{~L}$ clean bottle and used to estimate carbon and $\mathrm{NO}_{3}^{-}$uptakes after 6 days of incubation (called "Microcosm D6"). The remaining microcosm contents were kept for sampling and analysis.

\subsubsection{Carbon and nitrate uptakes}

Carbon (primary production) and $\mathrm{NO}_{3}-$ uptake rates were estimated in the same sample using the dual ${ }^{13} \mathrm{C} /{ }^{15} \mathrm{~N}$ isotopic label technique (Slawyk et al., 1977). Immediately after sampling, ${ }^{13} \mathrm{C}$ tracer $\left(\mathrm{NaH}^{13} \mathrm{CO}_{3}, 99\right.$ atom\%, Eurisotop, $\left.0.25 \mathrm{mmol}^{13} \mathrm{C} \mathrm{mL}^{-1}\right)$ and ${ }^{15} \mathrm{~N}$ tracer $\left(\mathrm{Na}^{15} \mathrm{NO}_{3}, 99\right.$ atom\%, Eurisotop, $1 \mathrm{mmol}^{15} \mathrm{~N} \mathrm{~mL}^{-1}$ ) were added to seawater mixtures at $10^{-3}: 1 \mathrm{v} / \mathrm{v}$ ratio. The initial enrichment was 10 atom\% excess of ${ }^{13} \mathrm{C}$ for the bicarbonate pool and $16-95$ atom\% excess of ${ }^{15} \mathrm{~N}$ for the $\mathrm{NO}_{3}{ }^{-}$pool depending on the ambient $\mathrm{NO}_{3}{ }^{-}$concentration. The ${ }^{13} \mathrm{C} /{ }^{15} \mathrm{~N}$ amended bottles were incubated for 24 $\mathrm{h}$ on the mooring line at the DCM and BEL depths, after which $1 \mathrm{~L}$ samples were filtered onto precombusted $\left(450{ }^{\circ} \mathrm{C}, 4 \mathrm{~h}\right)$ glass fiber filters (Whatman). Filters were stored at $-20^{\circ} \mathrm{C}$ and oven dried $\left(60{ }^{\circ} \mathrm{C}, 24 \mathrm{~h}\right.$ ) prior to analysis. Concentrations of carbon (POC), nitrogen (PON) as well as ${ }^{13} \mathrm{C}$ and ${ }^{15} \mathrm{~N}$ enrichments in particulate matter were measured with a mass spectrometer (Delta plus, ThermoFisher Scientific) coupled to a $\mathrm{C} / \mathrm{N}$ analyzer (Flash EA, ThermoFisher Scientific). Standard deviations were $0.009 \mu \mathrm{M}$ and $0.004 \mu \mathrm{M}$ for POC and PON, and 0.0002 atom\% and 0.0001 atom\% for ${ }^{13} \mathrm{C}$ - and ${ }^{15} \mathrm{~N}$-enrichments, respectively.

The absolute uptake rates $\left(\rho\right.$, in $\left.\mu \mathrm{mol} \mathrm{L}^{-1} \mathrm{~h}^{-1}\right)$ were calculated for nitrogen (Dugdale and Wilkerson, 1986) and carbon (Fernández et al., 2005) using the particulate organic concentrations measured after $24 \mathrm{~h}$ of incubation. These rates were converted into biomass specific uptake rates $(V$, in $\mu$ mol $\mu \mathrm{mol} \mathrm{POC}$ or $\mathrm{PON}^{-1} \mathrm{~h}^{-1}$ ) by dividing $\rho$ by $\mathrm{POC}$ or PON. The addition of ${ }^{15} \mathrm{~N}$ tracer would cause a substantial increase in dissolved inorganic nitrogen concentrations especially in the surface waters and, in turn, an overestimation of uptake rates (Dugdale and Wilkerson, 1986; Harrison et al., 1996). The $\mathrm{NO}_{3}^{-}$uptake rates were corrected for this perturbation (Dugdale and Wilkerson, 1986) using a half-saturation constant of $0.05 \mu \mathrm{mol} . \mathrm{L}^{-1}$ characteristic for nitrogen-poor oceanic waters (Harrison et al., 1996) and the measured $\mathrm{NO}_{3}{ }^{-}$concentration. Overestimation was low $(<5 \%)$ in samples with an addition of deep seawater but it was of about $50 \%$ in samples without deep seawater addition. The uptake rates measured in these samples represented therefore estimations rather than actual values. 
Biogeosciences Discuss., https://doi.org/10.5194/bg-2018-306

Manuscript under review for journal Biogeosciences

Discussion started: 2 August 2018

(c) Author(s) 2018. CC BY 4.0 License.

\subsubsection{Statistical analyses}

Kruskal-Wallis test was applied on the set of pigments concentrations, pico-phytoplankton abundances and macronutrients concentrations. If significant differences $(p<0.05)$ were found Mann-Whitney test was run to identify the samples significantly different. Statistical analyses were performed using Statgraphics Centurion XVI software.

\section{Results}

\subsection{Modeling of the deep seawater discharge}

\subsubsection{Model evaluation}

We compared modeled daily profiles (temperature, salinity) of June and November 2000 with in situ CTD data at OTEC station we recorded in June 2014 and November 2013 (Fig. 2 a-b).

In June, the modeled and observed vertical profiles of temperature were quite in agreement with a well mimicked thermocline depth. However, a warm bias of $\sim 1.5^{\circ} \mathrm{C}$ was simulated by the model in the top $50 \mathrm{~m}$. Between 300 and $500 \mathrm{~m}$ depth, a cold bias of $\sim 1.5^{\circ} \mathrm{C}$ depth was also observed. The modeled and experimental salinity profiles presented a similar pattern. However, the salinity was largely overestimated by the model in the top-120 m, especially in the upper $60 \mathrm{~m}$ (by 2 units), as compared to field observations. Between $120 \mathrm{~m}$ and $150 \mathrm{~m}$, the model slightly underestimated the salinity.

In November, the thermocline and halocline were well reproduced with modeled vertical profiles of temperature and salinity, in good agreement with observations. However, temperature was slightly overestimated by the model, with warm bias of $\sim 0.8^{\circ} \mathrm{C}$. At deeper depths, the modeled and observed temperatures were in excellent agreement. Salinity was underestimated by the model within the top $50 \mathrm{~m}$ by $\sim 1$ unit, and between 70 and $200 \mathrm{~m}$ depths by at maximum 0.3 units. Below $200 \mathrm{~m}$ depth, modeled and observed salinities exhibited similar profiles.

ADCP measurements (horizontal velocity and direction of currents) were made by our DCNS partner at the study site for a feasibility study, but in June 2011 (between 40 m and 800 m depths). ADCP data were compared to model outputs for June 2000 (Fig. 3). Current directions were quite similar between model outputs and ADCP data with a mean direction toward the South/South-East. The horizontal velocity norm was also quite close between both data sets with larger velocity close to the surface at $\sim 50 \mathrm{~m}$ depth. Larger difference appeared in subsurface in ADCP data but similar trends were observed and values were relatively close.

Modeled physical properties (temperature, salinity, currents) were therefore quite similar to those directly observed at the study site. The small differences observed between model and field data are 
Biogeosciences Discuss., https://doi.org/10.5194/bg-2018-306

Manuscript under review for journal Biogeosciences

Discussion started: 2 August 2018

(c) Author(s) 2018. CC BY 4.0 License.

likely due to inter-annual variability since years examined were indeed different for the model simulation (2000) and the field data (2011, 2013 and 2014).

\subsubsection{Impact of the deep seawater discharge on the thermal structure in surface}

In order to assess the deep seawater discharge impact on the thermal structure of the upper 150 $m$ of the water column, the dispersion of temperature differences $\left(\Delta T\right.$ in $\left.{ }^{\circ} \mathrm{C}\right)$ obtained without and with the deep seawater discharge in the model outputs was examined on two vertical sections. A section of $124 \mathrm{~km}$ for the large domain (corresponding to the child domain) and another section of $10 \mathrm{~km}$ for the near-OTEC domain (defined from $61.24^{\circ} \mathrm{W}$ to $61.17^{\circ} \mathrm{W}$ and $14.60^{\circ} \mathrm{N}$ to $14.67^{\circ} \mathrm{N}$ ) were defined, both centered on the OTEC site and parallel to the coast (Fig. 1). Presently, there are no environmental standards defining threshold levels for temperature difference that will be induced by an OTEC deep seawater discharge. So, the study relied on the World Bank Group prescriptions for liquefied natural gas facilities which set at $3{ }^{\circ} \mathrm{C}$ the temperature difference limit at the edges of the zone where initial mixing and dilution take place (IFC, 2007).

We thus considered for each discharge depth the cooling and warming outputs from the model, which exhibit a $|\Delta T| \geq 3{ }^{\circ} \mathrm{C}$. Areas (in \% of the considered domain) impacted by these cooling and warming effects were added (absolute values) in order to compare the potential impact of each discharge depth configuration. None of the discharge depth configurations could produce a modification of the thermal structure of the top $150 \mathrm{~m}$ of the water column, higher than or equal to the considered temperature threshold $\left(|\Delta T| \geq 3^{\circ} \mathrm{C}\right)$, for both domains sections.

Then, a lower temperature difference of $0.3^{\circ} \mathrm{C}$ (absolute value) was considered. This temperature difference represented a low threshold as compared to the World Bank Group prescriptions (IFC, 2007) that instead represent a high threshold. The areas exhibiting a $|\Delta T| \geq 0.3^{\circ} \mathrm{C}$ in the top $150 \mathrm{~m}$ (Table 2) were extremely small $\left(<1 \mathrm{~km}^{2}\right)$ and were not significantly different in both sections and at the different discharge depths, on an annual average and in June (our experimental period).

\subsection{Biogeochemical properties and phytoplankton community}

\subsubsection{Expected biogeochemical properties of the resulting mixed waters}

The $\mathrm{pH}$ was very similar at the DCM and BEL at the OTEC site on D6 (8.24 and 8.25, respectively), whereas deep seawater-pH showed lower value (7.81). The addition of $2 \%$ and $10 \%$ deep seawater to surface waters could thus induce a $\mathrm{pH}$-decrease of respectively, 0.01 and 0.07 unit. Hence, the effect on $\mathrm{pH}$ could be rather limited compared to the $0.1 \mathrm{pH}$ decrease (from 8.2 to 8.1 ) between the pre-industrial time and the 1990's [39]. 
Biogeosciences Discuss., https://doi.org/10.5194/bg-2018-306

Manuscript under review for journal Biogeosciences

Discussion started: 2 August 2018

(c) Author(s) 2018. CC BY 4.0 License.

$\mathrm{NO}_{3}{ }^{-}$and $\mathrm{PO}_{4}{ }^{3-}$ concentrations (Table 3 ) were below the detection limit $(<0.02 \mu \mathrm{M})$ at the DCM $(55 \mathrm{~m})$ and $\mathrm{BEL}(80 \mathrm{~m})$ at the OTEC site on observational D4 (June 16 $\left.{ }^{\text {th }} 2014\right)$, whereas $\mathrm{Si}(\mathrm{OH})_{4}$ concentrations were above detection limit $(>0.08 \mu \mathrm{M})$, particularly at the $\mathrm{DCM}(2.4 \mu \mathrm{M}) . \mathrm{NO}_{2}$ concentrations showed the highest values at the BEL whereas they were negligible at the DCM $(<0.02 \mu \mathrm{M})$. In deep seawater, as commonly observed, $\mathrm{NO}_{3}{ }^{-}, \mathrm{PO}_{4}{ }^{3-}$ and $\mathrm{Si}(\mathrm{OH})_{4}$ concentrations were largely higher compared to the surface (Table 3). The $2 \%$ and $10 \%$ deep water additions represented a large input for $\mathrm{NO}_{3}{ }^{-}$(from $<0.02 \mu \mathrm{M}$ to 0.54 and $2.71 \mu \mathrm{M}$, respectively). If the $10 \%$ ratio also induced a large input of $\mathrm{PO}_{4}{ }^{3-}$ (from $<0.02$ to $\left.0.19 \mu \mathrm{M}\right)$, the input of $2 \%$ deep water was more limited $(0.04 \mu \mathrm{M})$. The effect of $2 \%$ or $10 \%$ deep seawater addition was more limited for $\mathrm{Si}(\mathrm{OH})_{4}$ relatively to $\mathrm{NO}_{3}{ }^{-}$and $\mathrm{PO}_{4}{ }^{3-}$ input, yet it accounted for $50-63 \%$ increase for $10 \%$ deep seawater addition (Table 3). Finally, because deep and DCM waters were $\mathrm{NO}_{2}{ }^{-}$depleted, the deep seawater input did not modify the $\mathrm{NO}_{2}{ }^{-}$concentration at the DCM. At the $\mathrm{BEL}, \mathrm{NO}_{2}{ }^{-}$concentration was higher and the $10 \%$ addition slightly diluted $\mathrm{NO}_{2}{ }^{-}$at this depth.

Mn showed maximum concentrations in the surface layer on D4 at the OTEC site (Table 4) decreasing with depth as observed close to the Lesser Antilles in the Atlantic Ocean (Mawji et al., 2015), but the measured surface concentrations were particularly high, especially at the DCM. Fe that commonly dispatches hybrid distribution combining a nutrient-type profile in surface waters and a scavenged-type distribution in deep waters (Bruland, 2003) also exhibited high surface values, particularly at the DCM (Table 4). Cd, Zn, Co, Ni, and Cu dispatched nutrient-type profiles, whereas $\mathrm{Pb}$ exhibited scavenged-type profile (Nozaki, 1997; Gruber, 2008), but like for dissolved Fe and Mn, their concentrations in the upper waters were particularly high (Table 4). For all trace metals at both depths, the $2 \%$ deep seawater addition will not induce significant changes in their surface concentrations (Table 4). The $10 \%$ deep seawater addition could increase $\mathrm{Cd}, \mathrm{Ni}$ and $\mathrm{Zn}$ concentrations in surface waters (Table 4), whereas it would not constitute an input of $\mathrm{Pb}, \mathrm{Cu}, \mathrm{Co}$, and $\mathrm{Fe}$, and it can even dilute $\mathrm{Mn}$ (Table 4).

The surface waters can thus be enriched in macronutrients $\left(\mathrm{NO}_{3}{ }^{-}, \mathrm{PO}_{4}{ }^{3-}\right)$ when submitted to a deep seawater discharge (particularly with $10 \%$ deep seawater addition) in proportion depending on the depth. The same scheme can be applied in some of the dissolved trace metals $(\mathrm{Cd}, \mathrm{Ni}, \mathrm{Zn})$ when a large ratio of deep seawater (10\%) is discharged.

\subsubsection{Phytoplankton community in the natural environment}

A set of seven accessory pigments identified as biomarkers of specific taxa (Uitz et al., 2010; Table 5) were analyzed at OTEC station at D0, D4 and D6 in surrounding surface waters (Fig. 4), as well as population abundance and their biovolume using light microscopy (Fig. 5). 
Biogeosciences Discuss., https://doi.org/10.5194/bg-2018-306

Manuscript under review for journal Biogeosciences

Discussion started: 2 August 2018

(c) Author(s) 2018. CC BY 4.0 License.

The total chlorophyll a (TChl a defined as the sum of chlorophyll a and divinyl chlorophyll a), a proxy of the phytoplankton biomass, was higher at DCM than at BEL, as usually observed, by about two-folds. The fucoxanthin (biomarker of diatoms) concentrations were similar at the DCM and BEL on D0 (Fig. 4), like the total abundance of diatoms (Fig. 5). Fucoxanthin concentration increased by D4 and then by D6 at the DCM, corresponding to increases of cumulated diatoms biovolume on D4 (Fig. 5) and of diatoms abundance on D6 (Fig. 5). Peridinin, a biomarker of dinoflagellates, was detected at the DCM unlike at the BEL, with relatively high abundance and biovolume of dinoflagellates (Fig. 5). The 19'-hexanoyloxyfucoxanthin (biomarker of haptophytes) concentration (Fig. 4) and the prymmnesiophytes (haptophyte) abundance and biovolume (Fig. 5) showed higher values at the DCM than at the BEL only at D4.

At the DCM, dinoflagellates largely dominated the nano- and micro-phytoplankton assemblage with the largest abundance and biovolume. Whereas prymnesiophytes showed the second highest abundance, its biovolume was very low, on the contrary to diatoms that dispatched lower abundance but higher biovolume (Fig. 5). At the BEL, dinoflagellates, prymnesiophytes and diatoms showed similar abundance, dinoflagellates and the diatoms occupied the major part of the total biovolume. Three groups of dinoflagellates were observed by light microscopy but they could not be identified at species level. However, their small size and the lack of colored starch (using lugol) in the cytoplasm suggested they were mixotrophic or heterotrophic population. Furthermore, the low concentrations of peridinin in samples supported this assumption.

At both depths, light microscopy analyses suggested that the large cyanobacteria, mainly Trichodesmium sp., were low in abundance and biovolume. Flow cytometry identification and count indicated that the small cyanobacteria Prochlorococcus dominated the picophytoplankton assemblage, but they showed a significant decrease from D0 to D6 (Fig. 6). A significant portion of Synechococcus was also observed while picoeukaryotes were poorly represented. Both Prochlorococcus and Synechococcus showed higher abundance at the DCM than at the BEL (by $65 \%$ and $86 \%$, respectively), in line with the pigments analyses of zeaxanthin (biomarker of cyanobacteria) and total chlorophyll $b$ concentrations (prochlorophytes).

\subsubsection{Primary production and nitrate uptake in the natural environment}

The phytoplankton distribution and assemblage can partly drive the intensity of primary production, so the specific uptake rate of carbon ( $\mathrm{V}_{\mathrm{C}}$; Fig. 7) and $\mathrm{NO}_{3}{ }^{-}\left(\mathrm{V}_{\mathrm{NO}}-\right)$ were estimated at $\mathrm{DO}$ and D6. 
Biogeosciences Discuss., https://doi.org/10.5194/bg-2018-306

Manuscript under review for journal Biogeosciences

Discussion started: 2 August 2018

(c) Author(s) 2018. CC BY 4.0 License.

$V_{C}$ in surrounding surface waters was relatively low at DO (Fig. 7) indicating low primary production in these poor-nutrients waters. Yet, $V_{C}$ was approximately four-times higher at the DCM $\left(2.10^{-3} \mathrm{~h}^{-1}\right)$ than at the BEL $\left(5.10^{-4} \mathrm{~h}^{-1}\right)$ at D0, but drastically decreasing on D6 at the DCM (to $\sim 6.10^{-4}$ $\left.h^{-1}\right)$. $V_{\text {NO3- were also very low at } D 0}\left(1.10^{-3} h^{-1}\right.$ at DCM, $4.10^{-3} h^{-1}$ at BEL) and drastically decreased at D6, below the detection limit (data not shown).

\subsection{Impacts on the phytoplankton community of the deep seawater discharge}

\subsubsection{Changes in the phytoplankton assemblage}

At the DCM, TChl a was similar in all treatments $(p<0.05)$ after 6 days of incubation in microcosms (Fig. 8). Only fucoxanthin and 19'-butanoyloxyfucoxanthin showed significant $(p<0.05)$ higher concentrations in $10 \%$ enrichments as compared to controls, indicating higher abundance and/or biovolume of diatoms and haptophytes. The other diagnostic pigments did not show any significant difference between enriched microcosms and controls. Picoeukaryotes and Synechococcus abundances did not show significant variations between the treatments (Fig. 9a). Reversely, Prochlorococcus population showed higher $(p<0.05)$ abundance both in $2 \%$ and $10 \%$ enriched microcosms as compared to controls (Fig. 9a).

At the BEL, after the 6 days incubation period, pigments concentrations were below the detection limit indicating very low abundance of phytoplankton. Pico-phytoplankton did not show significant variations between the treatments and the controls (Fig. 9b). Pico-phytoplankton were clearly much less abundant at the BEL $\left(<1000\right.$ cells $\left.\mathrm{mL}^{-1}\right)$ than at DCM (Fig. 9b), 20-times even lower than that observed in surrounding waters at this depth on D6. For comparison, total abundance at the DCM was 5-times lower in incubated microcosms on D6 compared to surrounding surface waters.

\subsubsection{Changes in the primary production and nitrate uptake}

Deep water inputs (2\% and $10 \%$ ) to surrounding waters collected at the DCM on D0 led to an increase of $V_{C}$ within $24 \mathrm{~h}$ compared to the controls (by $43 \%$ and $48 \%$, respectively; Fig. 7); but they had no effect on D6 despite very low value in natural waters at this depth $\left(6.10^{-4} \mathrm{~h}^{-1}\right)$. The 6 days incubated microcosms showed very low $\mathrm{V}_{\mathrm{C}}$ in all treatments (Fig.7). At the BEL, $\mathrm{V}_{\mathrm{C}}$ were quite similar on D0 and D6 and after 6 days of incubation, without significant differences between the treatments

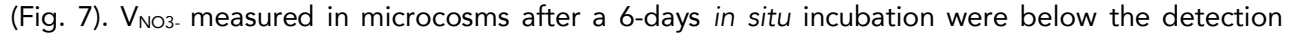
limit (data not shown). 
Biogeosciences Discuss., https://doi.org/10.5194/bg-2018-306

Manuscript under review for journal Biogeosciences

Discussion started: 2 August 2018

(c) Author(s) 2018. CC BY 4.0 License.

\section{Discussion}

\subsection{Natural variabilities in the oligotrophic area}

\subsubsection{Modeling of the deep seawater discharge}

Salinity field data showed large seasonal variations, with low values in June 2014 (34.6 on the top $50 \mathrm{~m}$ ) and much higher values in November 2013 (35.5 on the top $50 \mathrm{~m}$ ). The model run for year 2000 did not fully reproduce these variations. Indeed, salinity was overestimated by the model in June whereas it was underestimated in November. The observations we made at the OTEC station showed that the low salinity observed in June was associated with high $\mathrm{Si}(\mathrm{OH})_{4}$ concentrations. High $\mathrm{Si}(\mathrm{OH})_{4}$ levels in fresher seawater have been already reported in surface waters in the Caribbean Sea and they were attributed to Amazon and Orinoco fresh rivers inputs (Steven and Brooks, 1972; Moore et al., 1986; Muller-Karger et al., 1995; Hu et al., 2004). Fresh surface waters enriched in $\mathrm{Si}(\mathrm{OH})_{4}$ (Moore et al., 1986; Edmond et al., 1981) can be transported from the Amazon and Orinoco rivers towards the Caribbean Sea by the North Brazil Current and the Guiana Current (Muller-Karger et al., 1988, 1995; Osborne et al., 2014, 2015). It is likely that the rivers discharges and thus its inputs in the Caribbean Sea were quite different between 2000 (modeled year) and 2014 (in situ observations), thus explaining the discrepancy between modeled and observed salinities. Meso- and submeso-scale features resulting from the rivers flows could also induce short-term variability in the area and then could explain the observed differences.

\subsubsection{Biogeochemistry and phytoplankton community structure}

The very low $\mathrm{PO}_{4}{ }^{3-}$ and $\mathrm{NO}_{3}{ }^{-}$concentrations recorded in the oligotrophic surrounding surface waters were likely favorable to the development of small phytoplankton, especially to the cyanobacteria as shown with the significant occurrence of Prochlorococcus in these waters, which are typical of poor nutrient waters (Partensky et al., 1999). In line with the very low $\mathrm{V}_{\text {NO3- }}$ measured here, it has been shown that $\mathrm{V}_{\mathrm{NO}}$ - by Prochlorococcus represents indeed only 5-10\% of its nitrogen uptake whereas reduced nitrogen substrates $\left(\mathrm{NO}_{2}{ }^{-}\right.$, ammonium, and urea) uptake accounts for more than 90-95 \% (Casey et al., 2007). By contrast, the development of larger phytoplankton taxa (particularly diatoms), which have higher $\mathrm{NO}_{3}^{-}$and $\mathrm{PO}_{4}{ }^{3}$-requirements for their growth, were probably limited by these elements. Actually, $\mathrm{NO}_{3}{ }^{-}$and $\mathrm{PO}_{4}{ }^{3-}$ concentrations in surrounding waters at the DCM were both lower than the detection limit $(<0.02 \mu \mathrm{M}$ at D4) which is much lower than the average values of half-saturation constants for diatoms $\left(1.6 \pm 1.9 \mu \mathrm{M}\right.$ for $\mathrm{NO}_{3}{ }^{-}$and $0.24 \pm 0.29 \mu \mathrm{M}$ for $\mathrm{PO}_{4}{ }^{3-}$; Sarthou et al., 2005). For $\mathrm{Si}(\mathrm{OH})_{4}$, surrounding surface concentrations at DCM $(2.39 \mu \mathrm{M})$ were in the range of diatoms half-saturation constants $(3.9 \pm 5.0 \mu \mathrm{M}$; Sarthou et al., 2005), hence the 
Biogeosciences Discuss., https://doi.org/10.5194/bg-2018-306

Manuscript under review for journal Biogeosciences

Discussion started: 2 August 2018

(c) Author(s) 2018. CC BY 4.0 License.

diatoms development was probably not limited by $\mathrm{Si}(\mathrm{OH})_{4}$. Furthermore, diatoms showed low abundance in spite of relatively high $\mathrm{Si}(\mathrm{OH})_{4}$ and dissolved trace metals (in particular $\mathrm{Fe}$ ) concentrations in surface waters. The potential of Fe limitation on phytoplankton community has been reported previously in upwelling systems, with an apparent half-saturation constant for diatoms growth of $0.26 \mathrm{nM} F e$ in the Peru Upwelling system (Hutchins et al., 2002). This constant is far lower than the concentration of Fe measured in surrounding waters at DCM (1.08 $\pm 0.03 \mu \mathrm{M}$ at D4), suggesting that diatoms were probably not limited by Fe. This further supports growth limitation of diatoms by $\mathrm{NO}_{3}{ }^{-}$and/or $\mathrm{PO}_{4}^{3-}$.

Advection of waters from Amazon and Orinoco rivers can explain the relatively high $\mathrm{Si}(\mathrm{OH})_{4}$ observed in the Caribbean Sea. However, little information is available on the input of trace metals by these waters into the Caribbean Sea. Amazon river can be a source of dissolved $\mathrm{Fe}, \mathrm{Cu}, \mathrm{Ni}, \mathrm{Pb}$ and Co for the western-subtropical North Atlantic (Tovar-Sanchez and Sañudo-Wilhelmy, 2011), but this input can decrease rapidly away from its source like it has been shown for Co in the Western Atlantic (Dulaquais et al., 2014). Those inputs into the Caribbean Sea will have to be further examined, especially for $\mathrm{Fe}, \mathrm{Cd}, \mathrm{Ni}, \mathrm{Zn}, \mathrm{Mn}$ whose relatively high concentrations were detected in the $\mathrm{Si}(\mathrm{OH})_{4}$-enriched surface waters of this study. Additionally, other inputs of trace metals such as atmospheric deposition can also increase surface concentrations, and those inputs can be substantial (Shelley et al., 2012).

\subsubsection{Primary production}

Despite low $\mathrm{V}_{\mathrm{C}}$ on $\mathrm{D} 0$ and $\mathrm{D} 6$ at the $\mathrm{DCM}$, primary production still indicated much higher value on D0 compared to D6 that was associated with higher TChl a (Fig. 4a). The decrease of divinylchlorophyll a (Prochlorococcus) concentration [58] over the 6 days of observation can account for the decrease of TChl a, whereas chlorophyll a concentrations did not vary significantly during this period. The Prochlorococcus abundance was also lower by two-times on D6 compared to D0 (Fig. 6a). On the contrary, fucoxanthin (diatoms) increased by four-times over the 6 days (Fig. 4 a), as well as the diatoms abundance (by three-times; Fig. 5a). In turn, the increase in diatoms abundance was not associated with an increase in primary production. Instead, the observed decrease in primary production can be due to the decrease in Prochlorococcus abundance. In tropical and subtropical waters, pico-phytoplankton can indeed contribute to more than $80 \%$ of the primary production (Platt et al., 1983; Goericke and Welschmeyer, 1993). The development of diatoms population likely did not compensate the large decrease in Prochlorococcus abundance (from 141 to $6310^{3}$ cells $\mathrm{mL}^{-}$ $\left.{ }^{1}\right)$. 
Biogeosciences Discuss., https://doi.org/10.5194/bg-2018-306

Manuscript under review for journal Biogeosciences

Discussion started: 2 August 2018

(c) Author(s) 2018. CC BY 4.0 License.

\subsection{Impact of deep seawater discharge}

\subsubsection{Temperature effects}

The numerical simulation showed that the area impacted in the top-150 $\mathrm{m}$ by a temperature difference larger than or equal to $0.3{ }^{\circ} \mathrm{C}$ (absolute value) was lower than $1 \mathrm{~km}^{2}(\sim 2-3 \%$ of the considered domain) and was insensitive to the injection depth or to the size of the tested domain (Table 2). This suggests that temperature difference might rather be linked to internal variability of the system. Since the effect of the discharge appears undetectable within 2-3\% variation of the model, it can be deduced that in a worst-case scenario, only $3 \%$ of the small domain (300 m along the section, down to the $150 \mathrm{~m}$ depth) would be impacted by a temperature difference larger than or equal to $0.3^{\circ} \mathrm{C}$ (absolute value). The impact of a $0.3{ }^{\circ} \mathrm{C}$ temperature variation on the growth of diatoms, notably on Pseudonitzschia pseudodelicatissima species that were observed in our study area, is limited to a change in the growth rate of $0.03 \mathrm{~d}^{-1}[61]$. For Synechococcus, a $0.3{ }^{\circ} \mathrm{C}$ variation of the temperature would also have a limited impact on the growth, with a variation of only $0.02 \mathrm{~d}^{-1}$ (Boyd et al., 2013), like for Emiliania huxleyi (coccolithophyceae) for which the induced variation of maximum growth rate will be lower than $0.01 \mathrm{~d}^{-1}$ (Fielding, 2013). The thermal effect on the phytoplankton assemblage could thus be considered negligible.

\subsubsection{Impact on the phytoplankton community}

Microcosms enrichment of DCM waters with $10 \%$ of deep seawater led after 6 days to a significant increase $(p<0.05)$ of fucoxanthin (diatoms) and 19'-butanoyloxyfucoxanthin (haptophytes) by $71 \%$ and $77 \%$, respectively, as compared to the controls. If the $2 \%$ enrichment also showed similar trends, the differences of diagnostic pigments concentrations were not significant. $\mathrm{NO}_{3}{ }^{-}$and $\mathrm{PO}_{4}{ }^{3-}$ concentrations induced by $10 \%$ deep-water input on $\mathrm{DO}(2.57 \pm 0.13 \mu \mathrm{M}$ and $0.14 \pm 0.2 \mu \mathrm{M}$, respectively; Giraud et al., 2016) were close to $\mathrm{NO}_{3}{ }^{-}$and $\mathrm{PO}_{4}{ }^{3-}$ half-saturation constants of diatoms (1.6 $\pm 1.9 \mu \mathrm{M}$ and $0.24 \pm 0.29 \mu \mathrm{M}$, respectively; Sarthou et al., 2005). The $10 \%$ enrichment could thus support a development of diatoms. On the contrary, $\mathrm{NO}_{3}{ }^{-}$and $\mathrm{PO}_{4}{ }^{3-}$ enrichments induced by $2 \%$ addition of deep-water were too low $(0.57 \pm 0.02 \mu \mathrm{M}$ and $0.04 \pm 0.00$ $\mu \mathrm{M}$, respectively; Giraud et al., 2016) compared to these half-saturation constants to support the diatoms development. Therefore, the diagnostic pigments suggested a significant response proportionally to the amount of added deep seawater.

Prochlorococcus were also more abundant $(p<0.05)$ in $2 \%$ and $10 \%$ treatments as compared to the controls. This lack of further Prochlorococcus population increase in $10 \%$ treatments could be 
Biogeosciences Discuss., https://doi.org/10.5194/bg-2018-306

Manuscript under review for journal Biogeosciences

Discussion started: 2 August 2018

(c) Author(s) 2018. CC BY 4.0 License.

490

491

492

493

494

495

496

497

498

499

500

501

502

503

504

505

506

507

508

509

510

511

512

513

514

attributed to a higher grazing pressure by haptophytes and/or to $\mathrm{NO}_{3}{ }^{-}$and $\mathrm{PO}_{4}{ }^{3-}$ too rich conditions (Giraud et al., 2016).

Phytoplankton assemblage widely evolved in surrounding waters, from a predominance of picophytoplankton (Prochlorococcus) on D0 towards a higher abundance of micro-phytoplankton (diatoms) on D6. In order to assess if the impact on the phytoplankton assemblage due to $10 \%$ deep seawater addition (with a shift towards the diatoms) was in the range of the natural variation observed in the surrounding surface waters, $10 \%$ deep seawater microcosms phytoplankton assemblage was compared to the natural phytoplankton assemblage.

Whereas microcosm controls showed a lower Prochlorococcus abundance (Fig. 9a) than surrounding surface waters on D6 $(\mathrm{p}<0.05)$, the $10 \%$ microcosms additionally showed, higher fucoxanthin (diatoms) and 19'-butanoyloxyfucoxanthin (haptophytes) by about $142 \%$ and $317 \%$ (Fig. 8), respectively, as compared to natural waters at D6. Furthermore, $10 \%$ enrichments showed a fucoxanthin increase over the 6 days period by 3-times higher than in surrounding waters, whereas controls only showed an increase by 1.5-times higher than in surrounding waters. Therefore, it can be concluded that the $10 \%$ deep seawater enrichment induced higher variations of the phytoplankton assemblage than those observed from D0 to D6 in surrounding surface waters.

$V_{c}$ were higher $(p<0.05)$ both in $2 \%$ and $10 \%$ enrichments on D0 as compared to controls, suggesting a positive response of phytoplankton to the deep seawater addition. Conversely, there was no carbon-uptake rate difference $(p<0.05)$ between controls and enriched waters (with $2 \%$ and $10 \%$ of deep seawater) at D6 with the 6 days incubated microcosms, suggesting that the observed community modifications did not change the primary production. Indeed, the phytoplankton community was quite similar in surrounding surface waters on D6 and in 6 days-incubated microcosm controls. Thus, only the initial phytoplankton assemblage and initial primary production in surrounding surface waters would influence the response of the phytoplankton community and its production.

At the BEL, after 6 days of incubation, deep seawater addition experiments clearly showed lower effects on the phytoplankton community than at the DCM. Indeed, whereas significant differences $(p<0.05)$ between $10 \%$ enrichments and controls were observed in diagnostic pigments concentrations at the DCM, pigments concentrations were too low at the BEL to be quantified. It can be suggested that the lower population and lower carbon uptake could be related to the lowest light availability.

Overall, the phytoplankton response was proportional to the amount of added deep seawater. If the phytoplankton assemblage significantly varied over time in the environment, the $10 \%$ deep seawater enrichment showed larger variations (for diatoms and haptophytes) than those observed in 
Biogeosciences Discuss., https://doi.org/10.5194/bg-2018-306

Manuscript under review for journal Biogeosciences

Discussion started: 2 August 2018

(c) Author(s) 2018. CC BY 4.0 License.

the natural environment. The DCM should be more impacted than the BEL by the deep seawater discharge even with a large deep seawater input. On the other hand, the impact on the primary production largely depended on the initial phytoplankton assemblage, which was quite variable over time. The modification of the phytoplankton community to a deep seawater input could also be depending on the initial phytoplankton community. For that, the microcosm experiments did not allow drawing a scenario over the long term of the potential modifications of the primary production and the phytoplankton community associated to the deep seawater discharge by an OTEC.

Light microscopy analyses showed a large abundance of dinoflagellates at the DCM (between 9,240 and 20,400 cells $\mathrm{mL}^{-1}$ on D6 and D4; Fig. 5 a) which could be mixotrophic or heterotrophic and thus probably exert a grazing pressure on the phytoplankton, particularly on the pico-phytoplankton (Liu et al., 2002). However, in this study, the zooplankton larger than $200 \mu \mathrm{m}$ and its potential control on the phytoplankton community were not considered and should be examined in future studies.

\section{Conclusion}

Two complementary approaches were applied to study the potential effects of the deep seawater discharge of the planned OTEC plant on the phytoplankton community off Martinique.

Because the distribution and the development of phytoplankton are directly linked to the surface stratification, it is important to assess the thermal effect of deep seawater by an OTEC plant. Modelling of the deep seawater discharge showed that the thermal structure of the top $150 \mathrm{~m}$ of the water column on large and near-OTEC sections should be very slightly impacted for the lowest considered temperature differences $|\Delta T| \geq 0.3{ }^{\circ} \mathrm{C}$. If World Bank Group prescriptions of not exceeding a higher temperature difference of $3{ }^{\circ} \mathrm{C}$ are followed, the environmental perturbations potentially caused by the operation of the OTEC should be considered negligible. The area where the $150 \mathrm{~m}$-depth waters are impacted by the lowest considered temperature differences $|\Delta \mathrm{T}| \geq 0.3$ ${ }^{\circ} \mathrm{C}$ would not exceed $1 \mathrm{~km}^{2}$ in a worst-case scenario.

The phytoplankton community and its production could be impacted by a large deep seawater input. Whereas pico-phytoplankton currently largely dominates the phytoplankton assemblage, a ratio of $10 \%$ of deep seawater in DCM waters could induce a shift toward the diatoms and microphytoplankton. The ratio of $2 \%$ of deep seawater in DCM waters only showed significant higher Prochlorococcus abundance than controls, but the assemblage and the primary production were not modified by this lower input. The stimulation of Prochlorococcus could be due to one or some of the following causes: $\mathrm{NO}_{3}{ }^{-}$and/or $\mathrm{PO}_{4}{ }^{3-}$ supply, trace metal supply, lowered $\mathrm{pH}$ (higher availability of dissolved inorganic carbon). 
Biogeosciences Discuss., https://doi.org/10.5194/bg-2018-306

Manuscript under review for journal Biogeosciences

Discussion started: 2 August 2018

(c) Author(s) 2018. CC BY 4.0 License.

556 Although significant, these results would have to be extended to larger temporal scale, and the

557 phytoplankton interactions with higher trophic levels (such as zooplankton) must be studied.

558 Because no environment standards on the deep seawater discharge effects are available yet, a

559 rigorous monitoring of the phytoplankton community, biogeochemical parameters distribution and

560 of the water column stratification must be established as soon as the OTEC is implemented and

561 during its continuous functioning.

\section{Acknowledgements}

This work was supported by France Energies Marines and part of the IMPALA project. We would like to thank the Captains and crew members of the "Pointe d'Enfer", and the scientists in the laboratory at the University of the French West Indies and Guiana at Martinique; Dominique Marie (UPMC, Roscoff, France) and Christophe Lambert (LEMAR, France) for their help with the flow cytometry, and Anne Donval (LEMAR, France) for the pigment analyses. 
Biogeosciences Discuss., https://doi.org/10.5194/bg-2018-306

Manuscript under review for journal Biogeosciences

Discussion started: 2 August 2018

(c) Author(s) 2018. CC BY 4.0 License.

\section{References}

Agawin, N.S.R., Duarte, C.M., Agustí, S.: Nutrient and temperature control of the contribution of picoplankton to phytoplankton biomass and production. Limnology and Oceanography, 45(8), 1891-1891, 2000.

Aminot, A., and Kérouel, R.: Dosage automatique des nutriments dans les eaux marines : méthodes en flux continu. Ifremer Eds., Méthodes d'analyse en milieu marin, Quae, 2007.

Aure, J., Strand, O., Erga, S.R., Strohmeier, T.: Primary production enhancement by artificial upwelling in a western Norwegian fjord, Marine Ecology Progress Series, 39-470 52, 2007.

Bakun, A.: Global climate change and intensification of coastal ocean upwelling, Science, 247(4939), 198-201, 1990.

Boyd, P. W., Jickells, T., Law, C. S., Blain, S., Boyle, E. A., Buesseler, K. O., et al.: Mesoscale iron enrichment experiments 1993-2005: Synthesis and future directions, Science, 315(5812), 612-617, 2007.

Boyd, P.W., Rynearson, T.A., Armstrong, E.A., Fu, F., Hayashi, K., Hu, Z. et al.: Marine phytoplankton temperature versus growth responses from polar to tropical waters-outcome of a scientific community-wide study, PLoS One, 8(5), e63091, 2013.

Bruland, K. W., Rue, E. L., Smith, G. J.: Iron and macronutrients in California coastal upwelling regimes: Implications for diatom blooms, Limnology and Oceanography, 46, 1661-1674, 2001.

Bruland, K.W.: Controls on trace metals in seawater, The Oceans and Marine Geochemistry, Treatise on Geochemistry, 6, 23-47, 2003.

Brzezinski, M.A.: The Si:C:N ratio of marine diatoms. Interspecific variability and the effect of environmental variables, Journal of Phycology, 21, 347-357, 1985.

Carr, M. E., and Kearns, E. J.: Production regimes in four Eastern Boundary Current systems, Deep Sea Research Part II: Topical Studies in Oceanography, 50(22), 3199-3221, 2003.

Carton, J.A., and Giese, B.S.: A reanalysis of ocean climate using Simple Ocean Data Assimilation (SODA), Monthly Weather Review, 136(8), 2999-3017, 2008. 
Biogeosciences Discuss., https://doi.org/10.5194/bg-2018-306

Manuscript under review for journal Biogeosciences

Discussion started: 2 August 2018

(c) Author(s) 2018. CC BY 4.0 License.

596

597

598

599

600

601

602

603

604

605

606

607

608

609

610

611

612

Casey, J. R., Lomas, M.W., Mandecki, J., Walker, D.E.: Prochlorococcus contributes to new production in the Sargasso Sea deep chlorophyll maximum. Geophysical Research Letters, 34(10), 2007.

Chavez, F.P., Toggweiler, J.R.: Physical estimates of global new production: the upwelling contribution. In: Summerhayes, C.P., Emeis, K.C., Angel, M.V., Smith, R.L., Zeitzschel, B. (Eds.), Upwelling in the Ocean: Modern Processes and Ancient Records. Wiley, 313-320, 1995.

De Baar, H. J., Boyd, P. W., Coale, K. H., Landry, M. R., Tsuda, A., et al.: Synthesis of iron fertilization experiments: from the Iron Age in the age of enlightenment, Journal of Geophysical Research: Oceans (1978-2012), 110(C9), 2005.

Duarte, C.M., Agusti, S., Agawin, N.S.R.: Response of a Mediterranean phytoplankton community to increased nutrient inputs: a mesocosm experiment, Marine Ecology Progress Series, 195, 61-70, 2000.

Dugdale, R.C., and Wilkerson, F.P.: The use of ${ }^{15} \mathrm{~N}$ to measure nitrogen uptake in eutrophic oceans; experimental considerations, Limnology and Oceanography, 31(4), 673-689, 1986.

Dulaquais, G., Boye, M., Rijkenberg, M.J.A., Carton, X.J.: Physical and remineralization processes govern the cobalt distribution in the deep western Atlantic Ocean. Biogeosciences, 11(6), 15611580, 2014.

Dussart, B.M.: Les différentes catégories de plancton, Hydrobiologia, 26, 72-74, 1966.

Edmond, J. M., Boyle, E. A., Grant, B., Stallard, R.F.: The chemical mass balance in the Amazon plume I: The nutrients, Deep Sea Research Part A. Oceanographic Research Papers, 28(11), 1339$1374,1981$.

Escaravage, V., Prins, T.C., Smaal, A.C., Peeters, J.C.H.: The response of phytoplankton communities to phosphorus input reduction in mesocosm experiments, Journal of Experimental Marine Biology and Ecology, 198, 55-79, 1996.

Fernández, I., Raimbault, P., Garcia, N., Rimmelin, P., Caniaux, G.: An estimation of annual new production and carbon fluxes in the northeast Atlantic Ocean during 2001, Journal of Geophysical Research: Oceans (1978-2012), 110(C7), C07S13, 2005. 
Biogeosciences Discuss., https://doi.org/10.5194/bg-2018-306

Manuscript under review for journal Biogeosciences

Discussion started: 2 August 2018

(c) Author(s) 2018. CC BY 4.0 License.

623

624

625

626

627

628

629

630

631

632

Fielding, S.R.: Emiliania huxleyi specific growth rate dependence on temperature, Limnol. \& Oceanogr, 58(2), 663-666, 2013.

Giraud, M., Boye, M., Garçon, V., Donval, A., De La Broise, D.: Simulation of an artificial upwelling using immersed in situ phytoplankton microcosms, Journal of Experimental Marine Biology and Ecology, 475, 80-88, 2016.

Goericke, R. and Welschmeyer, N.A.: The Marine Prochlorophyte Prochlorococcus Contributes Significantly to Phytoplankton Biomass and Primary Production in the Sargasso Sea, Deep Sea Research Part I: Oceanographic Research Papers, 40(11), 2283-2294, 1993.

Goericke, R., and Repeta, D.J.: The pigments of Prochlorococcus marinus: The presence of divinyl chlorophyll $\mathrm{a}$ and b in a marine prochlorophyte. Limnology and Oceanography, 37, 425-433, 1992.

Gruber, N.: The marine nitrogen cycle: overview and challenges, Nitrogen in the marine environment, 1-50, 2008.

Handå, A., McClimans, T.A., Reitan, K.I., Knutsen, Ø., Tangen, K., Olsen, Y.: Artificial upwelling to stimulate growth of non-toxic algae in a habitat for mussel farming, Aquaculture Research, 45, 1798$1809,2014$.

Harrison, W.G., Harris, L.R., Irwin, B.D.: The kinetics of nitrogen utilization in the oceanic mixed layer: Nitrate and ammonium interactions at nanomolar concentrations, Limnology and Oceanography, 41(1), 16-32, 1996.

Hasle, G.R.: The inverted microscope method, In: Sournia, A. (Ed.), Phytoplankton Manual. UNESCO, Paris, 1988.

Hillebrand, H., Durselen, C.D., Kirchttel, D., Pollingher, U., Zohary, T.: Biovolume calculation for pelagic and benthic microalgae, Journal of Phycology, 35, 403-424, 1999.

Hooker, S.B., Clementson, L., Thomas, C.S., Schlüter, L., Allerup, M., Ras, J., Claustre, H., et al.: NASA Tech. Memo. 2012-217503, NASA Goddard Space Flight Center, Greenbelt, Maryland, 2012.

Hu, C., Montgomery, E.T., Schmitt, R.W., Muller-Karger, F.E.: The dispersal of the Amazon and Orinoco River water in the tropical Atlantic and Caribbean Sea: Observation from space and S- 
Biogeosciences Discuss., https://doi.org/10.5194/bg-2018-306

Manuscript under review for journal Biogeosciences

Discussion started: 2 August 2018

(c) Author(s) 2018. CC BY 4.0 License.

650

651

PALACE floats, Deep Sea Research Part II: Topical Studies in Oceanography, 51(10-11), 1151-1171, 2004.

Hutchins, D.A., Hare, C.E., Weaver, R.S., Zhang, Y., Firme, G.F., DiTullio, G.R., Alm, M.B., Riseman, S.F., Maucher, J.M., Geesey, M.E., Trick, C.G., Smith, G.J., Rue, E.L., Conn, J., Bruland, K.W.: Phytoplankton iron limitation in the Humboldt current and Peru upwelling, Limnology and Oceanography, 47, 997-1011, 2002.

International Finance Corporation (IFC): World Bank Group, Environmental, Health, and Safety Guidelines for Liquefied Natural Gas (LNG) Facilities, 2007.

Kagaya, S., Maeba, E., Inoue, Y., Kamichatani, W., et al.: A solid phase extraction using a chelate resin immobilizing carboxymethylated pentaethylenehexamine for separation and preconcentration of trace elements in water samples, Talanta, 79(2), 146-152, 2009.

Kress, N., Thingstad, T.F., Pitta, P., Psarra, S., Tanaka, T., Zohary, T., Groom, S., Herut, B., Mantoura, R.F.C., Polychronaki, T., Rassoulzadegan, F., Spyres G.: Effect of P and N addition to oligotrophic Eastern Mediterranean waters influenced by near-shore waters: a microcosm experiment, Deep Sea Research Part II: Topical Studies in Oceanography, 52, 3054-3073, 2005.

Liu, H., Suzuki, K., Saino, T.: Phytoplankton growth and microzooplankton grazing in the subarctic Pacific Ocean and the Bering Sea during summer 1999, Deep Sea Research Part I: Oceanographic Research Papers, 49(2), 363-375, 2002.

Lundholm, N., Skov, J., Pocklington, R., Moestrup, Ø.: Studies on the marine planktonic diatom Pseudo-nitzschia. 2. Autecology of P. pseudodelicatissima based on isolates from Danish coastal waters, Phycologia, 36(5), 381-388, 1997.

Marie, D., Partensky, F., Vaulot, D., Brussaard, C.: Enumeration of phytoplankton, bacteria, and viruses in marine samples, Current protocols in cytometry, 1-11, 1999.

Mawji, E., Schlitzer, R., et al.: The GEOTRACES intermediate data product 2014, Marine Chemistry, 177(1), 1-8, 2015, doi 10.1016/j.marchem.2015.04.005. ‘

Milne, A., Landing, W., Bizimis, M., Morton, P.: Determination of Mn, Fe, Co, Ni, Cu, Zn, Cd and Pb in seawater using high resolution magnetic sector inductively coupled mass spectrometry (HR-ICPMS). Analytica Chimica Acta, 665(2), 200-207, 2010. 
Biogeosciences Discuss., https://doi.org/10.5194/bg-2018-306

Manuscript under review for journal Biogeosciences

Discussion started: 2 August 2018

(c) Author(s) 2018. CC BY 4.0 License.

678

679

680

681

682

683

684

Moore, W.S., Sarmiento, J.L.R., Key, M.: Tracing the Amazon component of surface Atlantic water using ${ }^{228}$ Ra, salinity and silica, Journal of Geophysical Research: Oceans (1978-2012), 91(C2), $2574-$ 2580, 1986.

Muller-Karger, F.E., McClain, C.R., Richardson, P.L.: The dispersal of the Amazon's water. Nature, 333, 56-58, 1988

Muller-Karger, F.E., Richardson, P.L., McGillicuddy, D.: On the offshore dispersal of the Amazon's plume in the North Atlantic, Deep-Sea Research, 42, 2127-2137, 1995.

National Oceanic and Atmospheric Administration (NOAA): Ocean thermal energy conversion final environmental impact statement. Office of Ocean Minerals and Energy, Charleston, SC, 1981.

National Oceanic and Atmospheric Administration (NOAA): Ocean thermal energy conversion: Assessing potential physical, chemical, and biological impacts and risks. University of New Hampshire, Durham, NH, 2010.

Nozaki, Y.: A fresh look at element distribution in the North Pacific Ocean, Eos Transaction, 78(21), 221, 1997.

Orr, J.C, et al.: Anthropogenic ocean acidification over the twenty-first century and its impact on calcifying organisms, Nature, 437(7059), 681-686, 2005.

Osborne, A.H., Haley, B.A., Hathorne, E. C., Flögel, S., Frank, M.: Neodymium isotopes and concentrations in Caribbean seawater: Tracing water mass mixing and continental input in a semienclosed ocean basin, Earth and Planetary Science Letters, 406, 174-186, 2014.

Osborne, A.H., Haley, B.A., Hathorne, E. C., Plancherel, Y., Frank, M.: Rare earth element distribution in Caribbean seawater: Continental inputs versus lateral transport of distinct REE compositions in subsurface water masses, Marine Chemistry, 177, 172-183, 2015.

Partensky, F., Hess, W.R., Vaulot, D.: Prochlorococcus, a marine photosynthetic prokaryote of global significance, Microbiology and Molecular Biology Reviews, 63 (1), 106-127, 1999.

Pauly, D., and Christensen, V.: Primary production required to sustain global fisheries, Nature, 374(6519), 255-257, 1995. 
Biogeosciences Discuss., https://doi.org/10.5194/bg-2018-306

Manuscript under review for journal Biogeosciences

Discussion started: 2 August 2018

(c) Author(s) 2018. CC BY 4.0 License.

704

705

706

707

708

709

710

711

712

713

714

715

716

717

718

719

720

721

722

723

724

725

726

727

728

729

Platt, T., Rao, D. S., Irwin, B.: Photosynthesis of picoplankton in the oligotrophic ocean, Nature, 301, 702-704, 1983.

Rocheleau, G., Hamrick, J., Church, M.: Modeling the Physical and Biochemical Influence of Ocean Thermal Energy Conversion Plant Discharges into their Adjacent Waters, Final Technical Report, U.S. Department of Energy Award N DE-EE0003638, Makai Ocean Engineering, Inc., Kailua, Hawaii, 2012.

Sarthou, G., Timmermans, K.R., Blain, S., Tréguer, P.: Growth physiology and fate of diatoms in the ocean: a review, Journal of Sea Research, 53(1), 25-42, 2005.

Shchepetkin, A.F., and McWilliams, J.C.: Correction and commentary for "Ocean forecasting in terrain-following coordinates: Formulation and skill assessment of the regional ocean modeling system" by Haidvogel et al., J. Comp. Phys., 227, 3595-3624, Journal of Computational Physics, 228(24), 8985-9000, 2009.

Shchepetkin, A.F., and McWilliams, J.C.: The regional oceanic modeling system (ROMS): a splitexplicit, free-surface, topography-following-coordinate oceanic model, Ocean Modelling, 9(4), 347404, 2005.

Shelley, R. U., et al.: Controls on dissolved cobalt in surface waters of the Sargasso Sea: Comparisons with iron and aluminum, Global Biogeochem. Cycles, 26(2), GB2020, doi:10.1029/2011GB004155, 2012.

Slawyk, G., Collos, Y., Auclair, J.C.: The use of the ${ }^{13} \mathrm{C}$ and ${ }^{15} \mathrm{~N}$ isotopes for the simultaneous measurement of carbon and nitrogen turnover rates in marine phytoplankton, Limnology and Oceanography, 22, 925-932, 1977.

Steven, D.M., and Brooks, A.L.: Identification of Amazon River water at Barbados, W. Indies by salinity and silicate measurements. Marine Biology, 14, 345-348, 1972.

Taguchi, S., Jones, D., Hirata, J.A., Laws, E.A.: Potential effect of ocean thermal energy conversion (OTEC) mixed water on natural phytoplankton assemblages in Hawaiian waters. Bulletin of Plankton Society of Japan, 34(2), 125-142, 1987. 
Biogeosciences Discuss., https://doi.org/10.5194/bg-2018-306

Manuscript under review for journal Biogeosciences

Discussion started: 2 August 2018

(c) Author(s) 2018. CC BY 4.0 License. tropical North Atlantic Ocean, Biogeosciences, 8, 217-225, 2011.

733 Uitz, J., Claustre, H., Gentili, B., Stramski, D.: Phytoplankton class-specific primary production in the

734 world's oceans: seasonal and interannual variability from satellite observations, Global

735 Biogeochemical Cycles, 24(3), 2010.

736 Van Oostende, N., Dunne, J. P., Fawcett, S. E., Ward, B. B.: Phytoplankton succession explains size-

737 partitioning of new production following upwelling-induced blooms, Journal of Marine Systems, 148,

738 14-25, 2015. 
Biogeosciences Discuss., https://doi.org/10.5194/bg-2018-306

Manuscript under review for journal Biogeosciences

Discussion started: 2 August 2018

740

741

742

743

744

745

746

747

\begin{tabular}{|c|c|c|c|c|c|c|c|c|}
\hline & $\mathrm{Cd}(\mathrm{pM})$ & $\mathrm{Pb}(\mathrm{pM})$ & $\mathrm{Fe}(\mathrm{nM})$ & $\mathrm{Ni}(\mathrm{nM})$ & $\mathrm{Cu}(\mathrm{nM})$ & $\mathrm{Zn}(\mathrm{nM})$ & $\mathrm{Mn}(\mathrm{nM})$ & Co (pM) \\
\hline \multicolumn{9}{|l|}{ SAFe D2 } \\
\hline This study & $948.83 \pm 65.95$ & $28.86 \pm 4.44$ & $0.898 \pm 0.098$ & $8.60 \pm 0.36$ & $2.15 \pm 0.16$ & $7.29 \pm 0.27$ & $0.40 \pm 0.05$ & $40.12 \pm 3.88$ \\
\hline Consensus values & $986.00 \pm 23.00$ & $27.70 \pm 1.50$ & $0.933 \pm 0.023$ & $8.63 \pm 0.25$ & $2.28 \pm 0.15$ & $7.43 \pm 0.25$ & $0.35 \pm 0.05$ & $45.70 \pm 2.90$ \\
\hline$n=$ & 20 & 20 & 18 & 19 & 22 & 13 & 23 & 23 \\
\hline \multicolumn{9}{|l|}{ SAFe S } \\
\hline This study & $7.24 \pm 1.57$ & $48.42 \pm 6.08$ & $0.087 \pm 0.025$ & $2.56 \pm 0.55$ & $0.55 \pm 0.06$ & $0.07 \pm 0.06$ & $0.75 \pm 0.05$ & $2.85 \pm 0.81$ \\
\hline Consensus values & $1.10 \pm 0.30$ & $48.00 \pm 2.20$ & $0.093 \pm 0.008$ & $2.28 \pm 0.09$ & $0.52 \pm 0.05$ & $0.07 \pm 0.01$ & $0.79 \pm 0.06$ & $4.80 \pm 1.20$ \\
\hline$n=$ & 25 & 27 & 15 & 25 & 30 & 10 & 27 & 28 \\
\hline Detection Limit & 0.996 & 0.613 & 0.032 & 0.096 & 0.011 & 0.129 & 0.001 & 0.07 \\
\hline Blanks & 0.716 & 1.809 & 0.061 & 0.040 & 0.019 & 0.129 & 0.003 & 0.32 \\
\hline
\end{tabular}

748

749

750

751

752

753

754

Table 2- Area $\left(\mathrm{km}^{2}\right)$ impacted in the top-150 $\mathrm{m}$ by a temperature difference $|\Delta \mathrm{T}| \geq 0.3^{\circ} \mathrm{C}$ on two vertical sections centered on the OTEC, considering eight depths of deep seawater discharge (45, $80,110,140,170,250,350,500 \mathrm{~m}$ ), average and root mean square for the year 2000 (from the monthly data) and for June 2000.

\begin{tabular}{|c|c|c|c|c|}
\hline \multirow[b]{2}{*}{$\begin{array}{c}\text { Depth of deep } \\
\text { water } \\
\text { discharge }\end{array}$} & \multicolumn{2}{|c|}{ Mean Year 2000} & \multicolumn{2}{|c|}{ June 2000} \\
\hline & Large domain & $\begin{array}{c}\text { Near-OTEC } \\
\text { domain }\end{array}$ & Large domain & $\begin{array}{c}\text { Near-OTEC } \\
\text { domain }\end{array}$ \\
\hline $45 \mathrm{~m}$ & $0.4 \pm 0.4$ & $0.0 \pm 0.1$ & 0.0 & 0.0 \\
\hline $80 \mathrm{~m}$ & $0.6 \pm 0.7$ & $0.1 \pm 0.1$ & 0.4 & 0.0 \\
\hline $110 \mathrm{~m}$ & $0.6 \pm 0.5$ & $0.0 \pm 0.1$ & 0.9 & 0.0 \\
\hline $140 \mathrm{~m}$ & $0.4 \pm 0.5$ & $0.1 \pm 0.1$ & 0.1 & 0.0 \\
\hline $170 \mathrm{~m}$ & $0.5 \pm 0.8$ & $0.0 \pm 0.1$ & 0.5 & 0.0 \\
\hline $250 \mathrm{~m}$ & $0.5 \pm 0.7$ & $0.1 \pm 0.1$ & 0.1 & 0.0 \\
\hline $350 \mathrm{~m}$ & $0.5 \pm 0.5$ & $0.1 \pm 0.1$ & 0.0 & 0.0 \\
\hline $500 \mathrm{~m}$ & $0.5 \pm 0.5$ & $0.1 \pm 0.1$ & 0.3 & 0.0 \\
\hline
\end{tabular}

Table 1- Comparison of analyses of SAFe (Sampling and Analysis of iron) S and D2 reference samples (http://www.geotraces.org/science/intercalibration) between ID-ICPMS values (this study) and the consensus values. Our mean reagent blanks (based on all blank determinations) for dissolved $\mathrm{Cd}, \mathrm{Pb}, \mathrm{Fe}, \mathrm{Ni}, \mathrm{Cu}, \mathrm{Zn}, \mathrm{Mn}$ and $\mathrm{Co}$, and detection limits of ID-ICPMS estimated as three times the standard deviation of the mean reagent blanks are also shown.

(1)


Biogeosciences Discuss., https://doi.org/10.5194/bg-2018-306

Manuscript under review for journal Biogeosciences

Discussion started: 2 August 2018

(c) Author(s) 2018. CC BY 4.0 License.

Table 3- Nitrate, silicate, phosphate and nitrite concentrations on June $16^{\text {th }} 2014$ (D4) at the deep chlorophyll maximum (DCM), at the bottom of the euphotic layer (BEL), and at the deep seawater pumping depth. Concentrations were measured at the OTEC site ( $0 \%$ addition of deep waters) and calculated for $2 \%$ and $10 \%$ deep seawater additions.

772

\begin{tabular}{cccccc}
\hline $\begin{array}{c}\text { Depth } \\
(\mathrm{m})\end{array}$ & $\begin{array}{c}\text { Deep } \\
\text { seawater } \\
\text { ratio }\end{array}$ & $\begin{array}{c}{\left[\mathrm{NO}_{3}{ }^{-}\right]} \\
(\mu \mathrm{M})\end{array}$ & $\begin{array}{c}{\left[\mathrm{Si}(\mathrm{OH})_{4}\right]} \\
(\mu \mathrm{M})\end{array}$ & $\begin{array}{c}{\left[\mathrm{PO}_{4}{ }^{3}\right]} \\
(\mu \mathrm{M})\end{array}$ & $\begin{array}{c}{\left[\mathrm{NO}_{2}^{-}\right]} \\
(\mu \mathrm{M})\end{array}$ \\
\hline \multirow{3}{*}{$\mathrm{DCM}$} & $0 \%$ & $<0.02$ & 2.39 & $<0.02$ & 0.02 \\
& $2 \%$ & 0.54 & 2.88 & 0.04 & 0.02 \\
& $10 \%$ & 2.71 & 4.82 & 0.19 & 0.02 \\
\hline \multirow{3}{*}{$\mathrm{BEL}$} & $0 \%$ & $<0.02$ & 1.46 & $<0.02$ & 0.32 \\
& $2 \%$ & 0.54 & 1.96 & 0.04 & 0.32 \\
& $10 \%$ & 2.71 & 3.98 & 0.19 & 0.29 \\
\hline 1100 & $100 \%$ & 27.11 & 26.69 & 1.87 & $<0.02$ \\
\hline & & & & & \\
\hline
\end{tabular}

773

774

775

Table 4- Concentrations of dissolved trace metals (in $\mathrm{nM}$ ): $\mathrm{Mn}, \mathrm{Fe}, \mathrm{Cd}, \mathrm{Zn}, \mathrm{Co}, \mathrm{Ni}, \mathrm{Cu}, \mathrm{Pb}$ measured on June $16^{\text {th }} 2014$ (D4) at the OTEC site at the DCM, BEL and $1100 \mathrm{~m}$ (0 \% addition of deep waters), and their calculated concentrations in the mixtures with $2 \%$ and $10 \%$ addition of deep water.

\begin{tabular}{cccccccccc}
\hline $\begin{array}{c}\text { Depth } \\
(\mathrm{m})\end{array}$ & $\begin{array}{c}\text { Deep } \\
\text { seawater } \\
\text { ratio }\end{array}$ & $\mathrm{Mn}(\mathrm{nM})$ & $\mathrm{Fe}(\mathrm{nM})$ & $\mathrm{Cd}(\mathrm{nM})$ & $\mathrm{Zn}(\mathrm{nM})$ & $\mathrm{Co}(\mathrm{nM})$ & $\mathrm{Ni}(\mathrm{nM})$ & $\mathrm{Cu}(\mathrm{nM})$ & $\mathrm{Pb}(\mathrm{nM})$ \\
\hline \multirow{3}{*}{$\mathrm{DCM}$} & $0 \%$ & $2.97 \pm 0.17$ & $1.08 \pm 0.03$ & $0.03 \pm 0.01$ & $1.54 \pm 0.04$ & $0.05 \pm 0.00$ & $2.22 \pm 0.10$ & $1.70 \pm 0.18$ & $0.03 \pm 0.00$ \\
& $2 \%$ & 2.92 & 1.08 & 0.04 & 1.56 & 0.05 & 2.29 & 1.70 & 0.03 \\
& $10 \%$ & 2.71 & 1.09 & 0.07 & 1.63 & 0.05 & 2.60 & 1.71 & 0.03 \\
\hline \hline \multirow{3}{*}{$\mathrm{BEL}$} & $0 \%$ & $1.65 \pm 0.04$ & $0.68 \pm 0.03$ & $0.03 \pm 0.00$ & $0.65 \pm 0.03$ & $0.03 \pm 0.00$ & $2.26 \pm 0.17$ & $1.14 \pm 0.10$ & $0.03 \pm 0.00$ \\
& $2 \%$ & 1.63 & 0.69 & 0.04 & 0.68 & 0.03 & 2.34 & 1.15 & 0.03 \\
& $10 \%$ & 1.52 & 0.73 & 0.08 & 0.82 & 0.03 & 2.64 & 1.21 & 0.03 \\
\hline \hline 1100 & $100 \%$ & $0.34 \pm 0.02$ & $1.22 \pm 0.05$ & $0.45 \pm 0.01$ & $2.39 \pm 0.07$ & $0.06 \pm 0.00$ & $6.00 \pm 0.13$ & $1.80 \pm 0.08$ & $0.02 \pm 0.00$ \\
\hline
\end{tabular}

779

780

781

Table 5- Definition of the diagnostic pigments used as phytoplankton biomarkers (taxonomic

782 significance) and associated phytoplankton size class (Uitz et al., 2010).

783

\begin{tabular}{cccc}
\hline Diagnostic Pigments & Abbreviations & Taxonomic Significance & Phytoplankton Size Class \\
\hline Fucoxanthin & Fuco & Diatoms & microplankton \\
Peridinin & Perid & Dinoflagellates & microplankton \\
nanoplankton \\
19'-hexanoyloxyfucoxanthin & Hex-fuco & Haptophytes & nanoplankton \\
19'-butanoyloxyfucoxanthin & But-fuco & Pelagophytes and Haptophytes & nanoplankton \\
Alloxanthin & Allo & Cryptophytes & picoplankton \\
chlorophyll b + divinyl & TChlb & Cyanobacteria, Prochlorophytes & picoplankton \\
chlorophyll b & Zea & Chlorophytes, Prochlorophytes & \\
Zeaxanthin & & &
\end{tabular}

784 
Biogeosciences Discuss., https://doi.org/10.5194/bg-2018-306

Manuscript under review for journal Biogeosciences

Discussion started: 2 August 2018

(c) Author(s) 2018. CC BY 4.0 License.

\section{Figure captions}

Figure 1- Bathymetry of the parent and child (grey rectangle) domains interpolated from the GINA data base with a zoom on the near domain (black rectangle); the oblique white and black lines represent the large and small sections, respectively, used for numerical simulations.

Figure 2- Comparison of temperature and salinity between model outputs and field data at the OTEC station (a) on June $16^{\text {th }} 2000$ and 2014, respectively and (b) on November $28^{\text {th }} 2000$ and 2013, respectively.

Figure 3- Comparison of mean current direction and horizontal velocity norm between model outputs from June 2000 and ADCP data from June 2011.

Figure 4- Pigment concentrations (from HPLC analysis) at the OTEC site at the DCM (a) and at the BEL (b), on June 12 $2^{\text {th }}$ (D0), 16 ${ }^{\text {th }}$ (D4), 18 ${ }^{\text {th }}$ (D6) 2014 (bars represent the standard deviation).

Figure 5- Abundance and biovolume of micro- and part of nano-phytoplankton at the OTEC site on June $12^{\text {th }}(D 0), 16^{\text {th }}$ (D4), 18 $8^{\text {th }}$ (D6) 2014, at the DCM (a and c, respectively) and at the BEL (b and d, respectively) (bars represent the standard deviation).

Figure 6- Abundance of pico-phytoplankton at the DCM (a) and at the BEL (b), on June $12^{\text {th }}(\mathrm{D} 0)$, $16^{\text {th }}$ (D4), $18^{\text {th }}$ (D6) 2014 (bars represent the standard deviation).

Figure 7- Specific carbon uptake rate $\left(\mathrm{h}^{-1}\right)$ at the DCM (a) and BEL (b) depths, on June $12^{\text {th }}$ (D0), and $18^{\text {th }}$ (D6), and in 6 days incubated microcosms (D6), for the three mixing conditions $(0 \%, 2 \%$ and 10 $\%$ of deep seawater additions) (for surrounding waters bars represent the standard deviation for 3 replicates).

Figure 8- Diagnostic pigment concentrations in surrounding surface waters on D0 and D6, and in controls and deep water-enriched (2\% and $10 \%$ ) microcosms after 6 days of incubation at the DCM (bars represent the standard deviation). Similar letters ( $a, b$ or $c$ ) attributed to 2 or more treatments indicate no significant differences $(p<0.05)$ between these treatments.

Figure 9- Abundance of picophytoplankton in surrounding surface waters on day 0 and 6 , and in controls and deep water-enriched (2\% and $10 \%$ ) microcosms after 6 days of incubation at $45 \mathrm{~m}$ depth (a) and $80 \mathrm{~m}$ depth (b) (bars represent the standard deviation). Similar letters ( $\mathrm{a}, \mathrm{b}$ or $\mathrm{c}$ ) attributed to 2 or more treatments indicate no significant differences $(p<0.05)$ between these treatments. 
Biogeosciences Discuss., https://doi.org/10.5194/bg-2018-306

Manuscript under review for journal Biogeosciences

Discussion started: 2 August 2018

(c) Author(s) 2018. CC BY 4.0 License.

(c) (i)

826

827

828

832

833

834

835

Figure 1
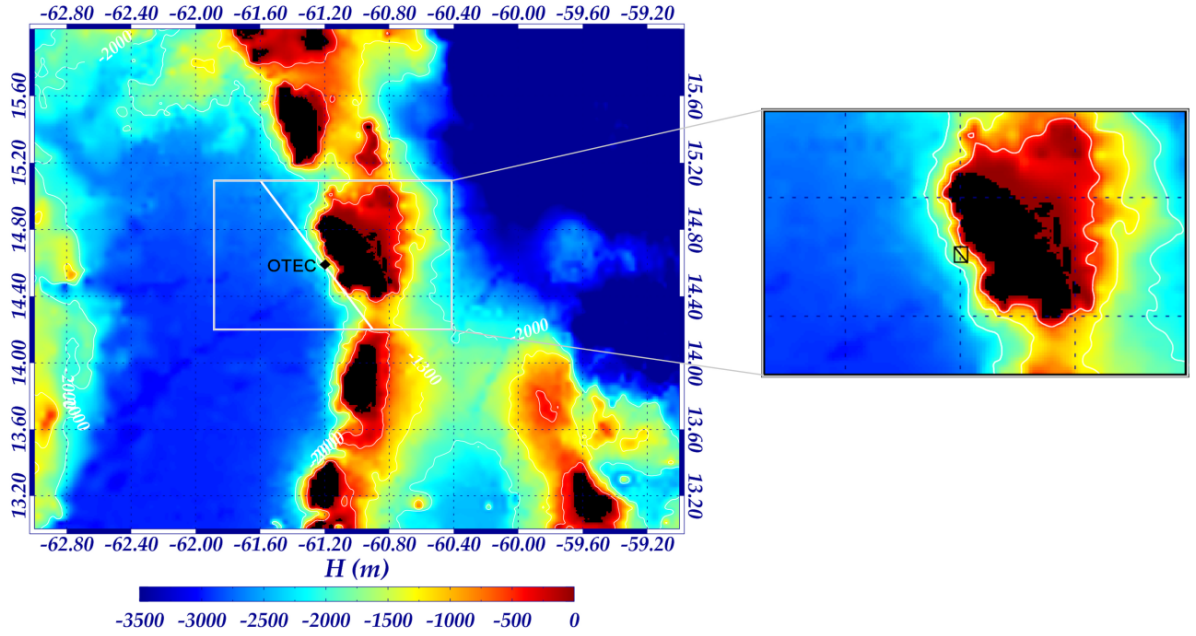

Figure 2

a)

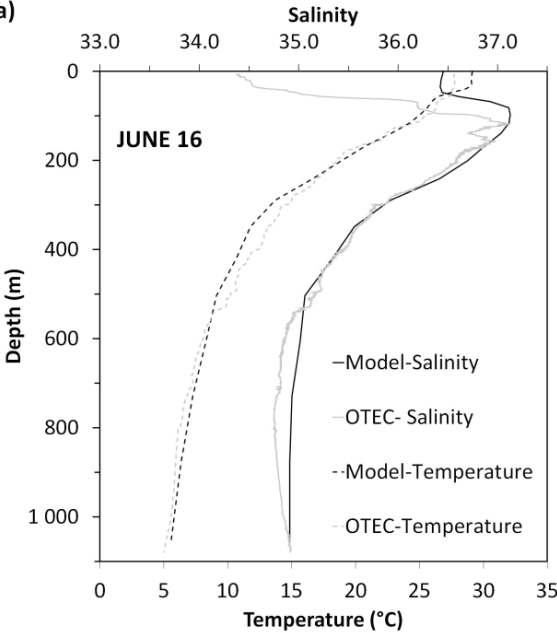

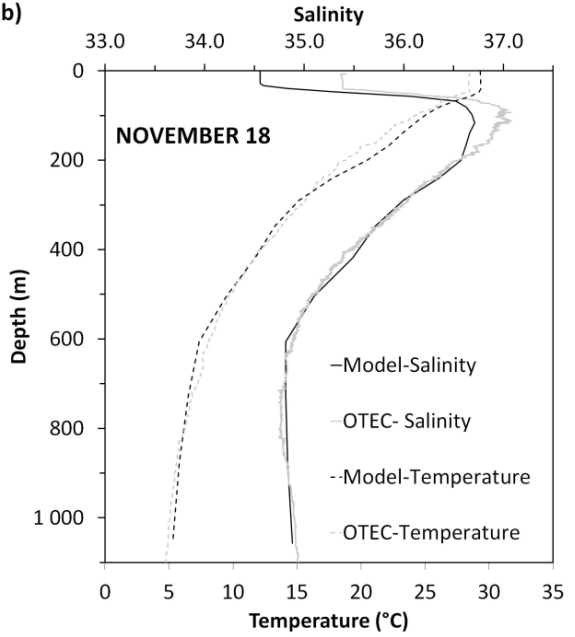


Biogeosciences Discuss., https://doi.org/10.5194/bg-2018-306

Manuscript under review for journal Biogeosciences

Discussion started: 2 August 2018

(c) Author(s) 2018. CC BY 4.0 License.

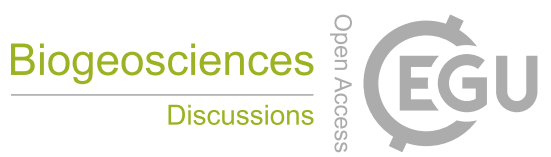

(c) (i)

842

843

844

845

846

847

848

849

850

851

852

853

854

855
Figure 3

a)

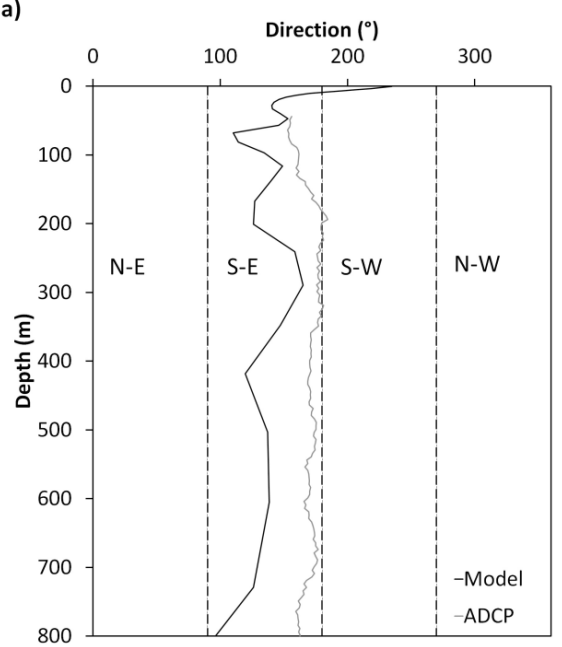

b)

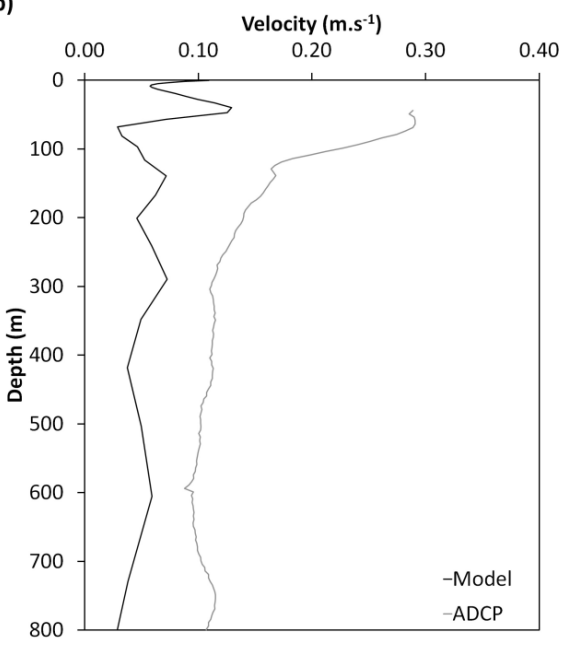

Figure 4
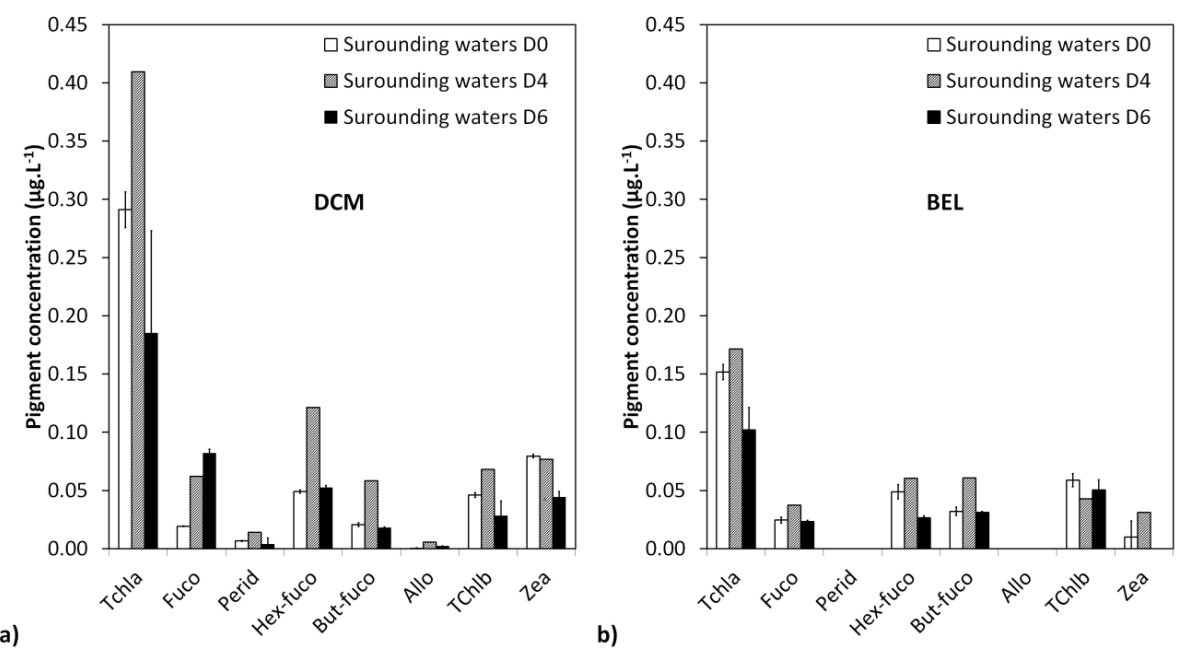
Biogeosciences Discuss., https://doi.org/10.5194/bg-2018-306

Manuscript under review for journal Biogeosciences

Discussion started: 2 August 2018

(c) Author(s) 2018. CC BY 4.0 License.

Figure 5
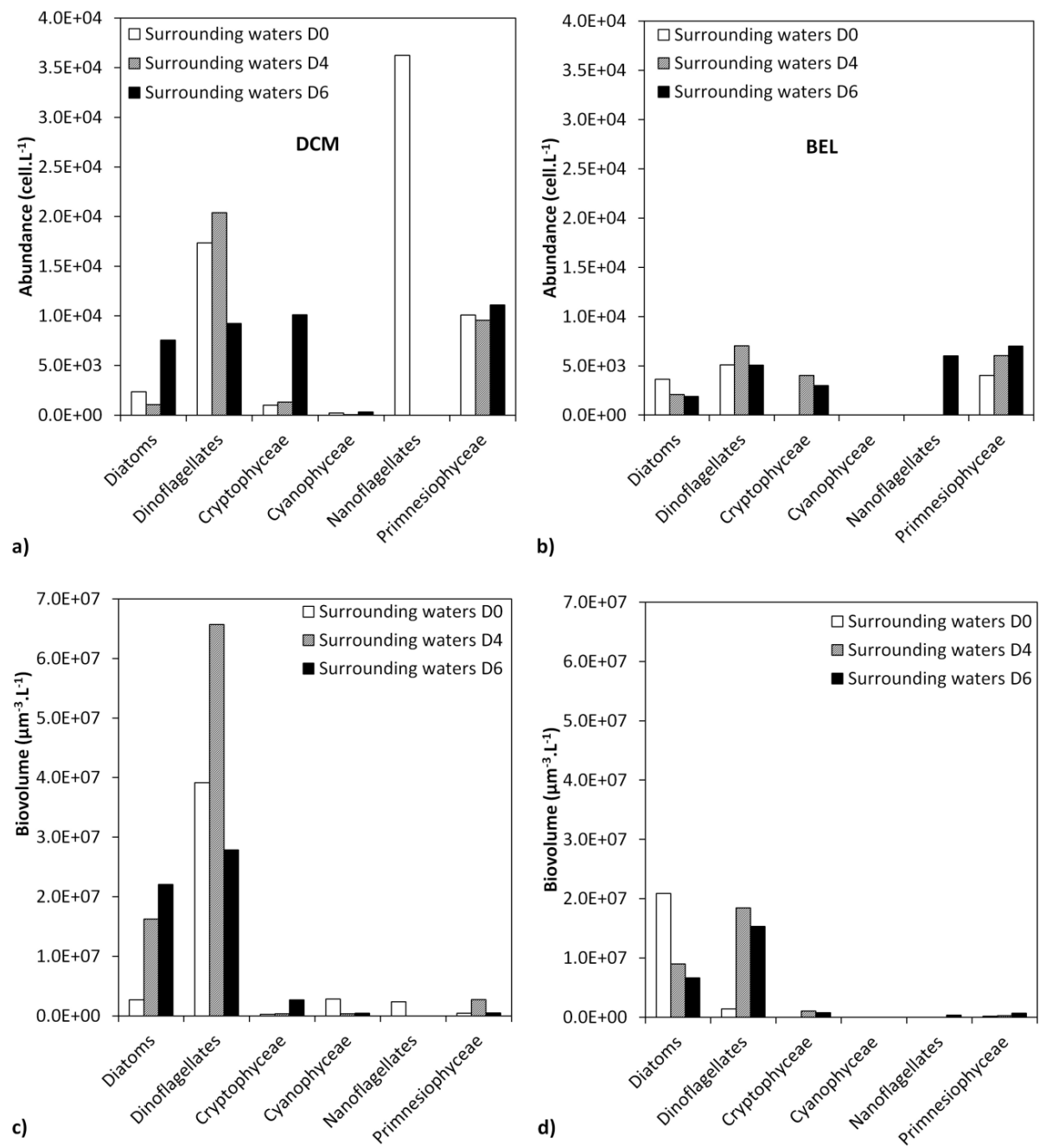
Biogeosciences Discuss., https://doi.org/10.5194/bg-2018-306

Manuscript under review for journal Biogeosciences

Discussion started: 2 August 2018

(c) Author(s) 2018. CC BY 4.0 License.

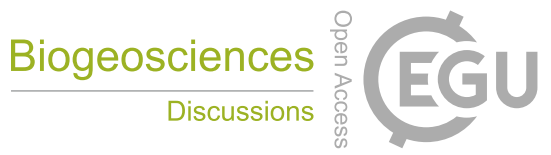

(c) $\underset{\mathrm{BY}}{(i)}$

875

876

877

878

879

882

883

884
Figure 6

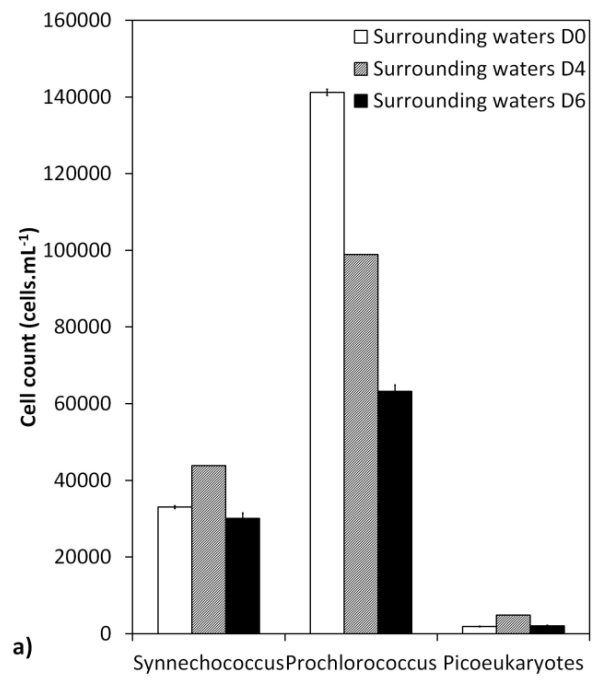

Figure 7

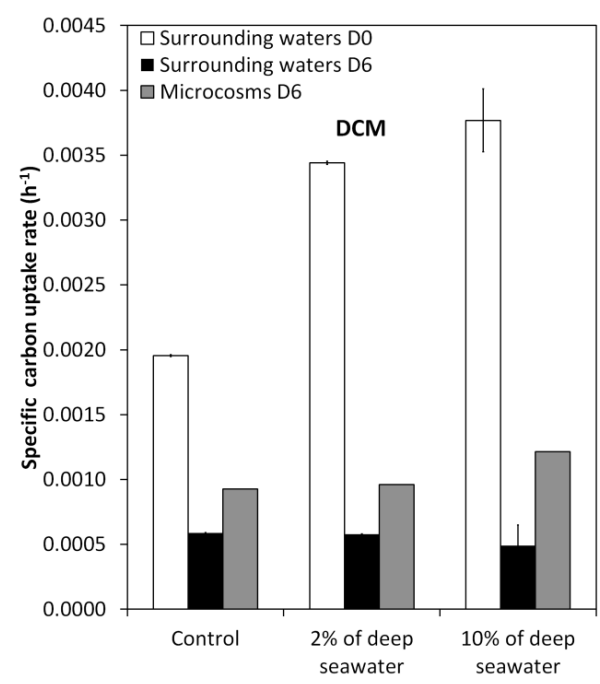

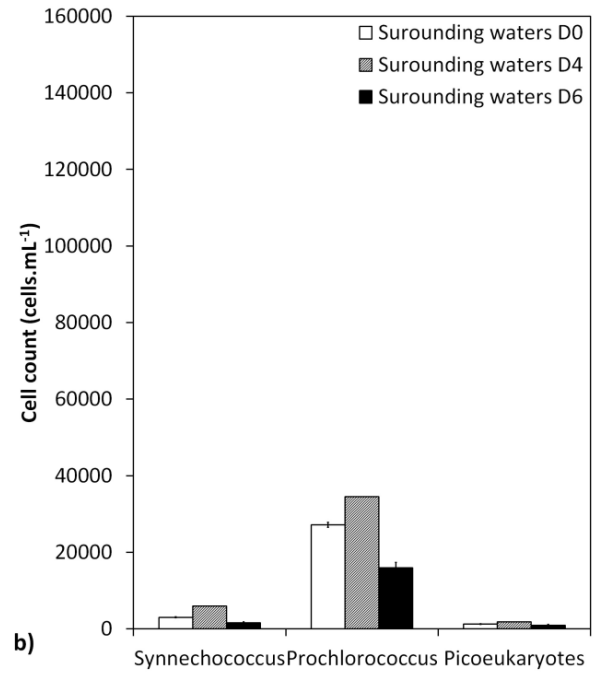

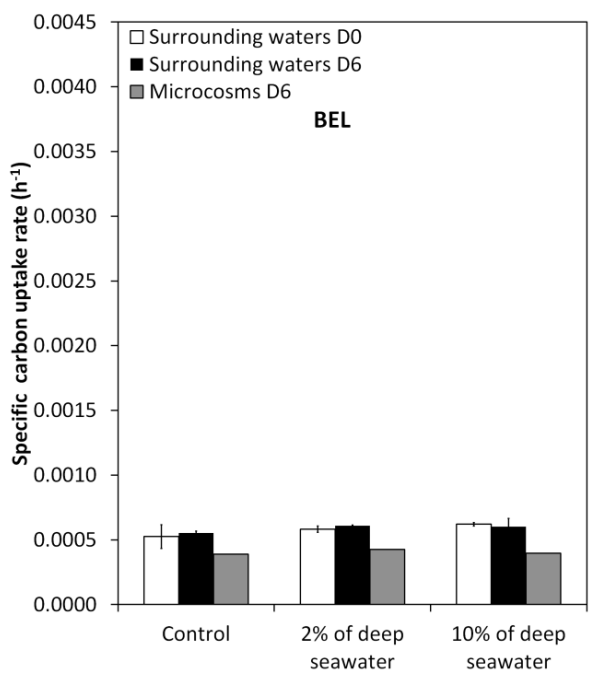


Biogeosciences Discuss., https://doi.org/10.5194/bg-2018-306

Manuscript under review for journal Biogeosciences

Discussion started: 2 August 2018

(C) Author(s) 2018. CC BY 4.0 License.

(c) (i)

892

893

894

895

896

897

898

899

900

\section{Figure 8}

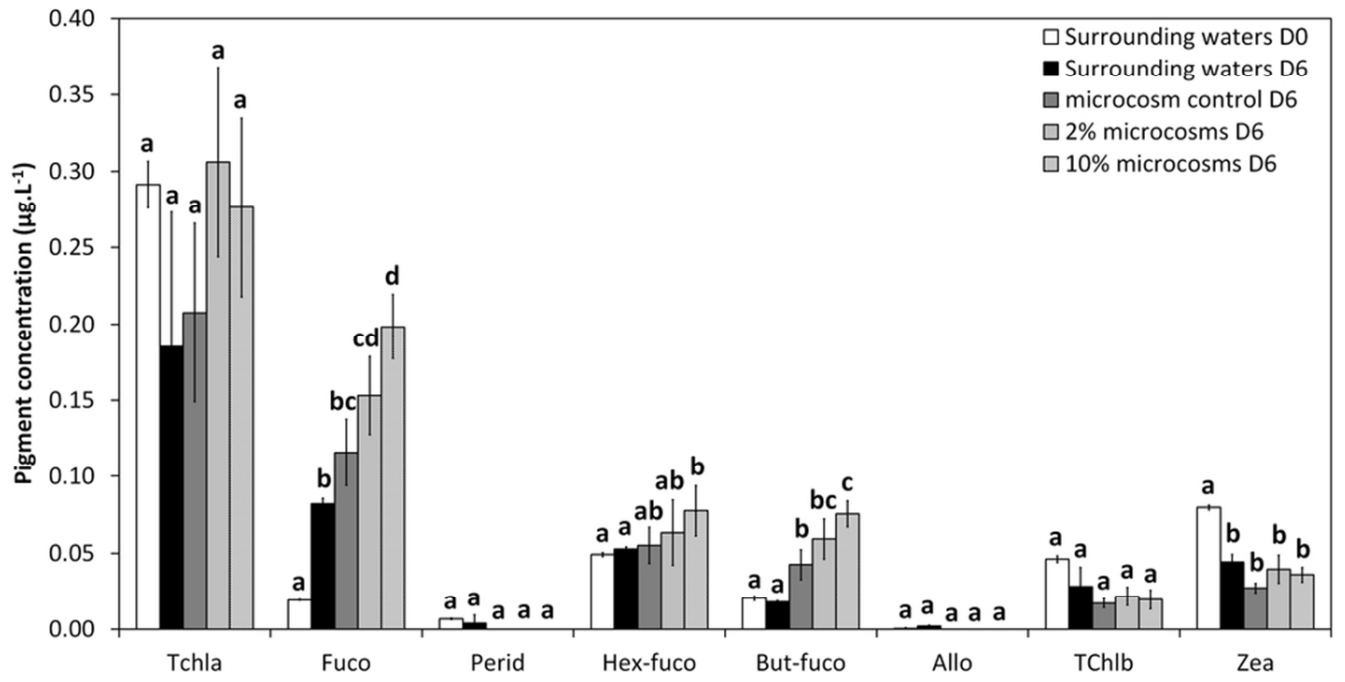

Figure 9
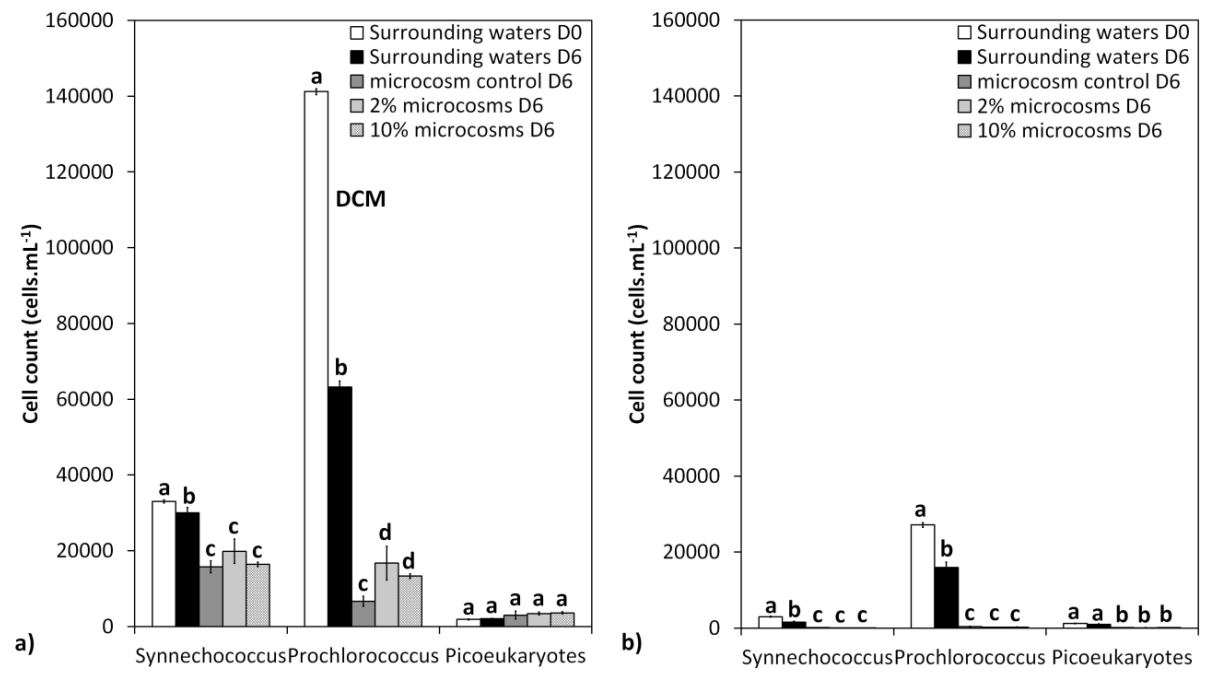